\title{
A instabilidade nas interações acionando circuitos-ambientes midiáticos: 0 caso do goleiro Aranha e da torcedora Patrícia Moreira
}

\section{The instability in interactions triggering media circuits- environments: the case of goalkeeper Aranha and rooter Patrícia Moreira}

\author{
Cintia Miguel Kaefer \\ Mestre em Comunicação na linha de pesquisa Midiatização e Processos Sociais do Programa \\ de Pós-Graduação em Comunicação da Universidade do Vale do Rio dos Sinos. Pós- \\ graduada em Comunicação com o Mercado pela Escola Superior de Propaganda e Marketing \\ de Porto Alegre. Atuação profissional voltada para a comunicação das organizações, com \\ experiência no relacionamento com a imprensa, comunicação com o público interno, ações \\ de marketing, coordenação de radioestrada, redes sociais, entre outros.
}

\section{Jairo Ferreira}

Professor Titular I do Programa de Pós-Graduação em Ciências da Comunicação da UNISINOS. Pos-doutor em comunicação pela UNR (Argentina). Atua principalmente nos seguintes temas: epistemologias da comunicação, midiatização, dispositivos, campos das mídias e circulação. Email: jferreira@unisinos.br

\section{Resumo}

O tema deste artigo são as relações entre meios e processos sociais, em caso de conflito simbólico que se instala a partir de um blow up: a torcedora Patrícia Moreira, em 2014, no jogo entre Grêmio e Santos, gritando a palavra 'ma-ca-co'. Esse objeto é construído enquanto circulação midiática. Essa é estudada como relações entre: meios, atores e instituições; deslocamentos simbólicos; e luta pelo reconhecimento . Esse objeto, amplo e diversificado, é aqui abordado em torno de uma questão específica: a incerteza nos processos midiáticos, configurada num ambiente-circuito imprevisível. A proposição é que os dilemas e impasses sócio-antropológicos não são apenas atualizados nos processos midiáticos, mas são também transformados pelo contato entre territórios antes estabilizados como relações de força (poder simbólico). A instabilidade nas interações é sugerida como núcleo ativador do processo circulatório.

Palavras-chave: midiatização; circulação; instabilidade; incerteza; blow-up.

\footnotetext{
Abstract

The themes of this article are the relations between the media and culture, through the symbolic conflict set from a blow-up: the supporter Patrícia Moreira, in 2014 at the match between Grêmio and Santos, yelled the word ma-ca-co (monkey). This theme is built as a mediatic circulation. The object, broad and diverse, is hereby approached around a specific issue: the uncertainty in the mediatic processes. The methodology used is the analysis of the interaction between actors, mediatic and mediatized institutions setting an unpredictable circuit environment. The proposal is that such socioanthropological dilemmas and impasses are not only up-to-date in mediatic processes, but are also changed by the contact between territories previously stable. Instability in interactions is suggested as the activating nucleus of the circulatory process.

Keywords: mediatization; circulation; instability; uncertainty; blow-up.
} 


\section{$1 \quad 0$ CASO}

A construção do caso Aranha-Patrícia Moreira é um recorte sobre as relações entre o futebol, o midiático e o racismo. Sendo caso, não pretende ser uma fórmula geral para análise dos outros casos semelhantes. O contexto reflexivo são as formulações sobre a midiatização (Ferreira, 2016), compreendidas como relações entre consumo, uso, práticas e apropriações dos meios e emergência de circuitos-ambientes. Instituições e atores, midiáticos e midiatizados, entram em interação e pode ocorrer a disrupção semiótica, com explosão de defasagens. A problemática sócio-simbólica que emerge nesse ambiente constituído passa a se constituir numa referência, talvez líquida, dos embates ocorridos e das questões comunicacionais. Oferece, em suas conclusões, proposições para análise dos fluxos semióticos, que configuram circuitos-ambientes amplos, envolvendo dezenas de instituições midiáticas, midiatizadas e atores midiáticos e midiatizados. Se instala um concerto (WATZLAWICK, BEAVIN, JACKSON, 1991), inesperado e imprevisível (PRIGOGINE, 1996), revelando a incompletude da racionalidade como referência da resolução de conflitos.

\subsection{A semiose acionada pelos processos midiáticos}

Disruptiva, a semiose coloca em xeque as interações discursivas histórica e socialmente estabilizadas enquanto práticas (habitus). O signo macaco - que poderia estar estabilizado nas relações étnicas no sul do Brasil - fica instabilizado pelo contato entre diversos territórios simbólicos instituídos ad hoc, em interação em processos midiáticos.

Isso não significa que o signo macaco estivesse em uma zona de sentidos compartilhados, confortável. Já havia defasagem antes, nas relações discursivas marcadas pelos meios e dispositivos conforme o modelo canônico. Certamente, o signo macaco teria significados diversos entre os seus emissores e seus destinatários, no sul, no âmbito dos emissores e dos destinatários. Mesmo assim é possível inferir que não era a mesma configuração para públicos localizados em territórios simbólicos diversos. A proposição é de que esses processos de contato atualizam, transformam, negam e superam as defasagens históricas e sociais conhecidas, questionando-as inclusive, não necessariamente no sentido de instalar novas normas e valores sociais que sejam simbolicamente reconhecidos como meios e poder, mas, inúmeras vezes, no sentido da instabilização das relações sociais, colocando em xeque a capacidade adaptativa da espécie.

Nas interações em rede digitais (diversos meios, atores e instituições), as lógicas de produção midiática e midiatizada estão em sinergia com lógicas de reconhecimento, num processo que se sobrepõe à investigação da circulação conforme o modelo canônico que referencia Verón (1997, p.15). Nesse modelo, a produção, de um lado, está representada por um contexto e lógica específica de produção - dos meios ditos de massa - e a recepção por diversos contextos e diversas lógicas de reconhecimento - de atores ou instituições outras. Nas redes, o consumo, uso, práticas e apropriações dos meios, na esfera da produção, por atores e instituições, midiatizadas e midiáticas, os coloca em sinergia indeterminada, em que cada polo é produtor e receptor, e, portanto, apresenta-se como contexto e lógicas de produção e, ao mesmo tempo, 
como contexto e lógicas de recepção, perante outros. Há uma explosão, exponencial, de uma luta pelo reconhecimento, derivada da multiplicação das lógicas de produção que retroage sobre essas, inclusive, como contextos de produção. Explosão, portanto, das defasagens, aceleração das interações e luta pelo reconhecimento dos sentidos em disputa (Ferreira, 2016).

Mas essa é uma hipótese teórico-metodológica muito vasta. Ampla. Nem sempre há explosão. Muitos acontecimentos midiáticos, inclusive sobre o racismo ficam restritos aos circuitos regulados pelas estratégias de contenção de sentidos. Alguns acontecimentos é que se propagarão em circuitos cada vez mais amplos. A construção do Aranha-Patrícia tem essa especificidade.

\subsection{Um fio para investigar objetos em expansão/explosão: dos indícios às relaç̃oes, das lógicas ao analógico}

Já na análise da circulação conforme seu modelo, Verón (2001) identificou a problemática da circulação como espaço de incerteza e indeterminação. Essa identificação é central em sua crítica aos estudos em comunicação que tem como referência a possibilidade de se estabelecer uma relação entre mapa sócio-demográfico e sentido, nas interações discursivas. Essa formulação já tinha também sido inferida por nós (Ferreira, 2002), na análise das interações em listas de discussões. Isso demanda a pesquisa empírica que supere a análise sócio-demográfica de condutas. Esse é o ponto convergente com Verón (2001).

Em outro artigo (Ferreira, 2016), sugerimos que nesse espaço de interações complexas, a compreensão das relações que se instalam devem recorrer a analogia. O analógico pode ser, pelo prefixo an, negação, oposição, separação, diminuição, falta ou reforço de lógica. Essa multiplicidade semântica dá ao termo um lugar especial na solução que buscamos para o método para análise de processos não lineares, em que sentimentos e experiências, existência e forma se articulam na analítica e crítica sobre os processos midiáticos. Essa sugestão não nega a existência de lógicas específicas nos processos midiáticos. Mas informa que a investigação, ao deparar-se com diversas lógicas específicas, em defasagens diversas, deve transitar para um espaço reflexivo mais fluído, em que a negação das lógicas, suas oposições, separações, redução de força, falta ou mesmo reforço, são concomitantes, conforme o caso em investigação.

Atualizando nossa formulação: na análise das interações comunicacionais em rede é impossível antecipar a especificidade dos circuitos, dos ambientes de interação, dos novos paradigmas de interação que emergem, das narrativas reconstruídas, dos pontos de bifurcação, da sucessão de bifurcações, das defasagens decorrentes, dos trajetos e vias dominantes, das subordinadas que as alimentam, etc. Por isso, a importância das operações analógicas.

\section{CORPUS}

O corpus foi organizado em três movimentos: a) captura de materiais conforme posições nos meios em rede: instituições e atores midiáticos e midiatizados envolvidos com o tema escolhido; b) os materiais foram distribuídos conforme espaços sociais (campos), instituições e atores; c) distribuídos na 
linha do tempo, onde se procurou estabelecer uma narrativa do acontecimento midiático. Esse trabalho, exaustivo, permitiu fazer um mapa do circuito ambiente constituído e um desenho do caso geral:

\begin{tabular}{|c|c|c|c|}
\hline Notícias & $\begin{array}{l}\text { Meios de instituições/ } \\
\text { campos } \\
\downarrow\end{array}$ & $\begin{array}{l}\text { Meios de ações } \\
\text { individuais } \\
\downarrow\end{array}$ & $\begin{array}{l}\text { Sítios de ações } \\
\text { coletivas emergentes } \\
\downarrow\end{array}$ \\
\hline Instituições midiáticas & $\begin{array}{l}\text { Instituições } \\
\text { midiatizadas }\end{array}$ & Consumo difuso. & $\begin{array}{l}\text { Coletivos não } \\
\text { institucionalizados }\end{array}$ \\
\hline $\begin{array}{l}\text { "Textos" que } \\
\text { viram notícia. } \\
\text { Reconhecimento em } \\
\text { instituições específicas } \\
\text { do campo das mídias. }\end{array}$ & $\begin{array}{l}\text { Passagem dos textos } \\
\text { que viram notícia em } \\
\text { outras instituições } \\
\text { (governos, empresas, } \\
\text { etc.). Reconhecimento } \\
\text { em outros campos. } \\
\text { Leituras institucionais. }\end{array}$ & $\begin{array}{l}\text { Passagem dos textos } \\
\text { que viram notícia } \\
\text { por fora de campos } \\
\text { institucionalizados. } \\
\text { Exemplo: Espaço de } \\
\text { atores individuais. } \\
\text { Leituras individuais. } \\
\text { Exemplo: face }\end{array}$ & $\begin{array}{l}\text { A construção de novos } \\
\text { sistemas coletivos de } \\
\text { inteligibilidade. }\end{array}$ \\
\hline $\begin{array}{l}\text { Imagem da ESPN, } \\
\text { Portal G1, Uol, Jornal } \\
\text { Folha de São Paulo... }\end{array}$ & $\begin{array}{l}\text { Santos, Grêmio, STJD, } \\
\text { Brigada Militar }\end{array}$ & $\begin{array}{l}\text { Torcedores, indivíduos } \\
\text { em geral }\end{array}$ & $\begin{array}{l}\text { Meios de ativismo, } \\
\text { Comunidades no } \\
\text { Facebook }\end{array}$ \\
\hline
\end{tabular}

Figura 1 - Circuito-ambiente constituído na pesquisa ${ }^{1}$ (Fonte: Ferreira; Kaefer)

O acontecimento Aranha constituiu-se como um dispositivo social temporário, pois em um espaço determinado de tempo acionou diferentes atores e trouxe à discussão tensões em torno do racismo como paradigma relacional. $\mathrm{E}$ isso vem ao encontro do entendimento do Ferreira (2005) sobre o papel da epistemologia da midiatização na atualidade, que rompe com a proposta de reprodução de dilemas pré-existentes nas relações sociais.

Entende-se que são instalados novos dilemas em um novo espaço de sentidos, que implica não somente em outra escala, mas também em outra problemática - aquela definida pelos novos territórios desenhados pela semiose emergente na circulação midiática. (Ferreira, 2005, p.2).

Estes novos territórios são mais complexos e marcam a ruptura com os habitus (sistemas de inteligibilidade) desenvolvidos em territórios anteriores. A linearidade dá lugar a novos ambientes, multilineares e multipolares. Partindo destas referências a respeito da instalação dos novos territórios de interações e conversações sociais e a partir do entendimento destas novas lógicas presentes na sociedade em vias de midiatização, é possível analisar a problemática da circulação na condução do caso protagonizado pelo goleiro Aranha e pela torcedora Patrícia Moreira.

Assim, para o entendimento de um circuito-ambiente constituído nas interações discursivas midiatizadas, é possível refletir sobre a circulação enquanto defasagem entre valores, normas e crenças diferenciadas, e, ao mesmo, como processo que gesta novas referências, abertas. Para isso, serão utilizados dois procedimentos. O primeiro apresentará a cronologia do caso Aranha a partir dos atos discursivos que geraram processos de interações discursivas midiatizadas mais intensas, colocando em sinergia instituições midiáticas, midiatizadas e atores. O segundo visa mostrar o fio condutor que manteve em destaque o acontecimento

$1 \quad$ Ferreira, 2005 
e seus desdobramentos.

\section{BIFURCAÇ̃̃ES, INSTABILIDADE E TENTATIVAS DE FECHAMENTO NO CIRCUITO}

A cronologia parte do pressuposto de que as interações discursivas não são reversíveis, isto é, são irreversíveis, o que implica que são marcadas pelo tempo de sua ocorrência. É um momento descritivo, e, ao mesmo tempo, inferencial, a partir do caso desenhado. Estão descritos os acontecimentos relativos ao objeto de pesquisa que tiveram as sinergias em termos de interações junto às instituições e atores, midiáticos e midiatizados. São fatos que geraram curtidas, comentários, compartilhamentos e outras repercussões no universo digital com maior alcance de pessoas em meios constituídos. A diagramação desse processo nos sugere inferências pontuais e, depois, transversais.

O esquema a seguir ilustra o processo através de um sistema com bifurcações que, através de uma temporalidade, demonstra a sequencia de ações relativas ao caso midiático abordado como caso de investigação:

\section{Figura 3 -Bifurcações sucessivas do caso Aranha}

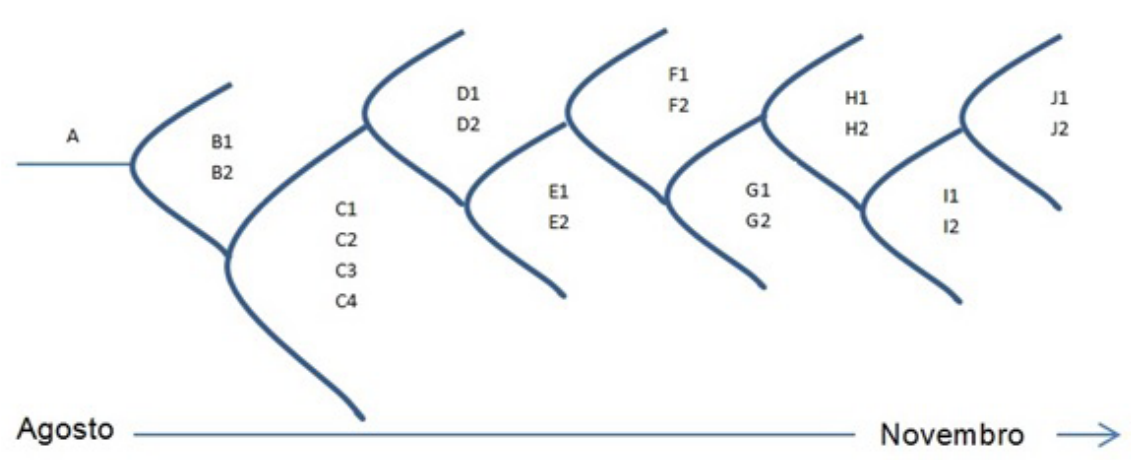

Fonte: Autora. (2016).

As bifurcações indicam um campo de possibilidades, pois seus diferentes caminhos podem gerar diferentes desdobramentos. Nesse sentido, a análise determinista não é pertinente. A não linearidade em um sistema como esse implica no encontro de soluções múltiplas. É possível enxergar esse esquema também como espécie de ondas, onde uma vai se sobrepondo à outra, mantendo o sistema aberto e sem conclusões.

A seguir, serão detalhados os códigos que compõe a figura acima para o entendimento dos fatos sucessivos que compuseram o caso de estudo, em que são usadas metáforas para ilustração dos temas articulados. Os fatos se referem ao período que o caso Aranha esteve em maior destaque junto aos meios de comunicação, através de pautas e reportagens sobre o desenrolar do assunto. A referência, portanto, é do período de 28 de agosto, data da realização do jogo pela Copa do Brasil, até o dia 24 de novembro, dia da 
audiência realizada no Foro Central de Porto Alegre, em que os quatro torcedores gremistas tiveram julgamento penal suspenso e receberam a punição de apresentação obrigatória na delegacia de polícia durante todos os jogos do Grêmio pelo período de 10 meses.

$\mathrm{Na}$ análise, inferimos que é possível observar que a sucessão de fatos novos, perseguições, dilemas e posicionamentos diversos mantiveram o assunto em destaque durante estes, aproximadamente, quatro meses. $\mathrm{O}$ caso Aranha gerou um sistema instável, que não se manteve em audiência em decorrência de uma instituição ou de um fato isolado. Foram sucessivas ocorrências protagonizadas ora por Aranha, ora por Patrícia Moreira, ora por uma instituição midiática, ou por uma instituição midiatizada, que constituem o caso midiático enquanto dilema sócio-cultural do racismo. Segundo Prigogine (1996), podemos confirmar que neste caso, o caos gerou maiores interações do que geraria em um sistema de linearidade.

\subsection{A primeira onda: A FOCALIZAÇÃO}

A linha do tempo de constituição do circuito está representada com o ponto de partida:

\section{Figura 4 - Início das bifurcaç̃es}

A

Fonte: Autora. (2016).

O goleiro Aranha é o protagonista principal desse momento, dando início ao acontecimento ao chamar o canal de Esportes ESPN para registrar ofensas racistas recebidas de grupo de torcedores gremistas atrás do gol do Santos na partida de futebol contra o Grêmio. É ele quem chama a atenção para a manifestação dos torcedores. Se Aranha tivesse seguido a partida sem dar importância aos insultos da torcida contrária, a sociedade teria conhecimento dos fatos racistas ocorridos em campo? 


\section{Figura 5 - Imagem da reprodução de gravação do canal ESPN}

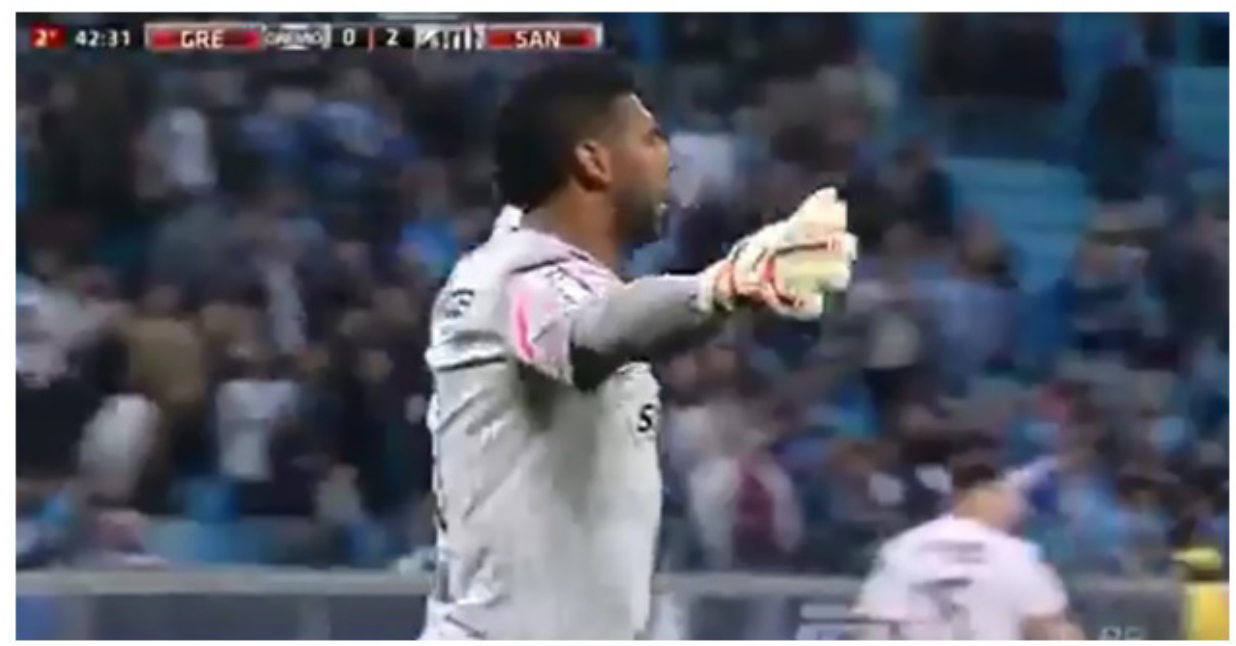

Fonte: Uol Mais. São Paulo, 29 ago, 2014. Disponível em

¿http://mais.uol.com.br/view/e0qbgxid79uv/video-da-espn-mostra-torcedora-do-gremiochamando-aranha-de-macaco-04020D193272DC895326?types=A\&>Aces so em 02 out. 2014.

A metáfora se insere no contexto dos atores individuais midiatizados, porque foi oriunda da ação-interação de Aranha com os meios, que pediu a atenção do juiz e das câmeras de televisão para o acontecimento. Em uma partida de futebol, em que existem interesses múltiplos em campo, o goleiro do Santos chama o olhar das pessoas para algo diferente. Por isso denominamos esse recorte como focalização, pois oriunda do foco que o Aranha deu ao assunto, ou seja, às ofensas que vinha recebendo em campo. Assim, esse é o ponto A, que dá início ao sistema de bifurcações apresentado a seguir.

\section{Figura 6 - Símbolo da propagação no sistema de bifurcações}

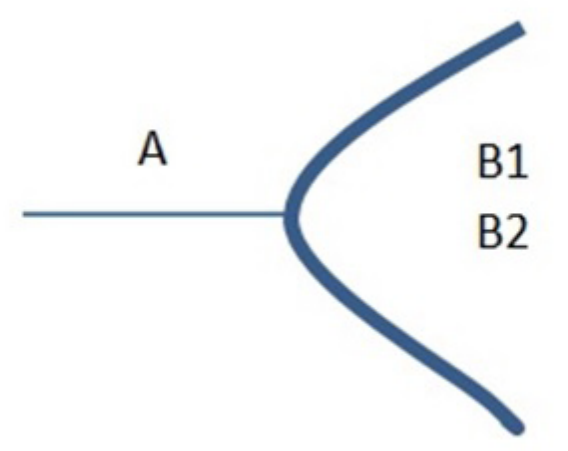

Fonte: elaborado pela Autora(2016).

O B1 representa o Canal de Esportes ESPN, que reproduz, ao vivo, a imagem dos torcedores emitindo sons e grunhidos relacionados ao "macaco" e recorta a imagem da Patrícia Moreira falando a palavra ma-ca-co, silabicamente. A imagem foi repetida nos minutos finais da realização do jogo. 
Figura 7 - Imagem da torcedora Patrícia Moreira reproduzida pela ESPN

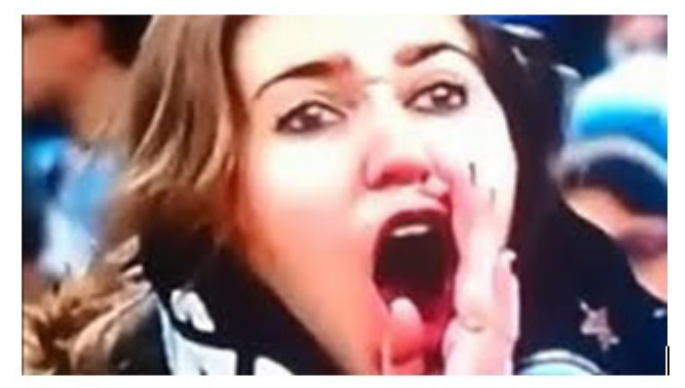

Fonte: Uol Mais. São Paulo, 29 ago, 2014. Disponível em

$<$ http://mais.uol.com.br/view/e0 qbgxid79uv/video-da-espn-mostra-torcedora-do-gremiochamando-aranha-de-macaco-04020D193272DC895326?types=A\&>Acesso em 02 out. 2014.

No B2 estão os torcedores do Grêmio, que fazem insultos racistas ao goleiro do Santos. Ou seja, o embate ocorre através do enfrentamento do goleiro Aranha ao grupo de torcedores atrás do gol. Chamar o canal televisivo para realizar as filmagens foi uma forma de reação, de tentar punir ou corrigir a torcida.

Figura 8 - Imagem de parte do grupo de torcedores ofendendo o goleiro Aranha

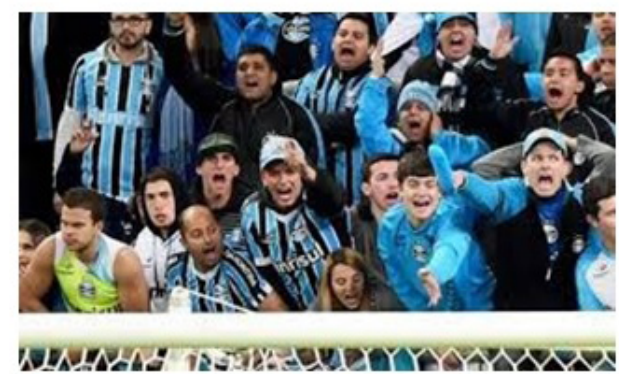

Fonte: Uol Mais. São Paulo, 29 ago, 2014. Disponível em

http://mais.uol.com.br/view/e0 qbgxid79uv/video-da-espn-mostra-torcedora-do-gremiochamando-aranha-de-macaco-04020D193272DC895326?types=A\&>Acesso em 02 out. 2014.

\subsection{A segunda onda: a acusação, o procura-se $E$ a expiação}

Se as imagens gravadas ficassem no plano geral, haveria propagação? O plano geral - uma operação técnica, mas também semio-social, dissolveria o processo em um julgamento geral do racismo, já estabelecido? O que especificou foi a focalização? A expiação gerou instabilidade no processo? São perguntas só aparentemente retóricas. Nossa formulação é de que essa a instabilidade do processo é acionada por um blow up, resultado de interações atores e instituições midiáticas. A partir desse momento, há a propagação nos meios, que passaram a reproduzir massivamente a imagem da torcida gremista ofendendo o goleiro Aranha. A imagem se transformou em ícone, conforme os diagramas abaixo. 
Figura 9 - Imagem de parte do grupo de torcedores ofendendo o goleiro Aranha

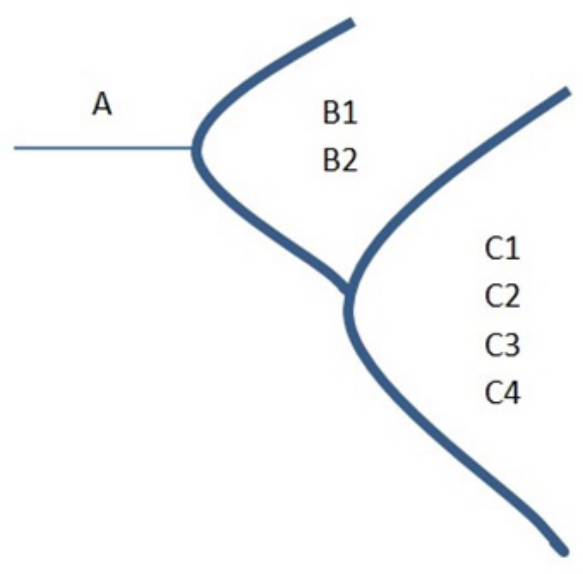

Fonte: elaborado pela Autora(2016).

A letra C é o maior ponto no sistema de bifurcações que, mesmo se mostrando aberto, neste ponto, possui uma série de fatos constituintes da instalação do dilema.

A primeira classificação da letra $\mathrm{C}$ recorda os fatos imediatos ocorridos após o jogo entre Santos e Grêmio. O C1 lembra que Aranha dá entrevista ao final do jogo e comenta com os repórteres sobre injúrias racistas recebidas da torcida, relatando que não era a primeira vez que o fato ocorria no Rio Grande do Sul e que não pretendia prestar denúncia sobre o acontecimento. Mas Aranha não sabia do alcance da propagação da imagem da Patrícia Moreira, que começou a circular antes mesmo do término da partida.

Figura 10 - Imagem da entrevista coletiva reproduzida pelo canal ESPN

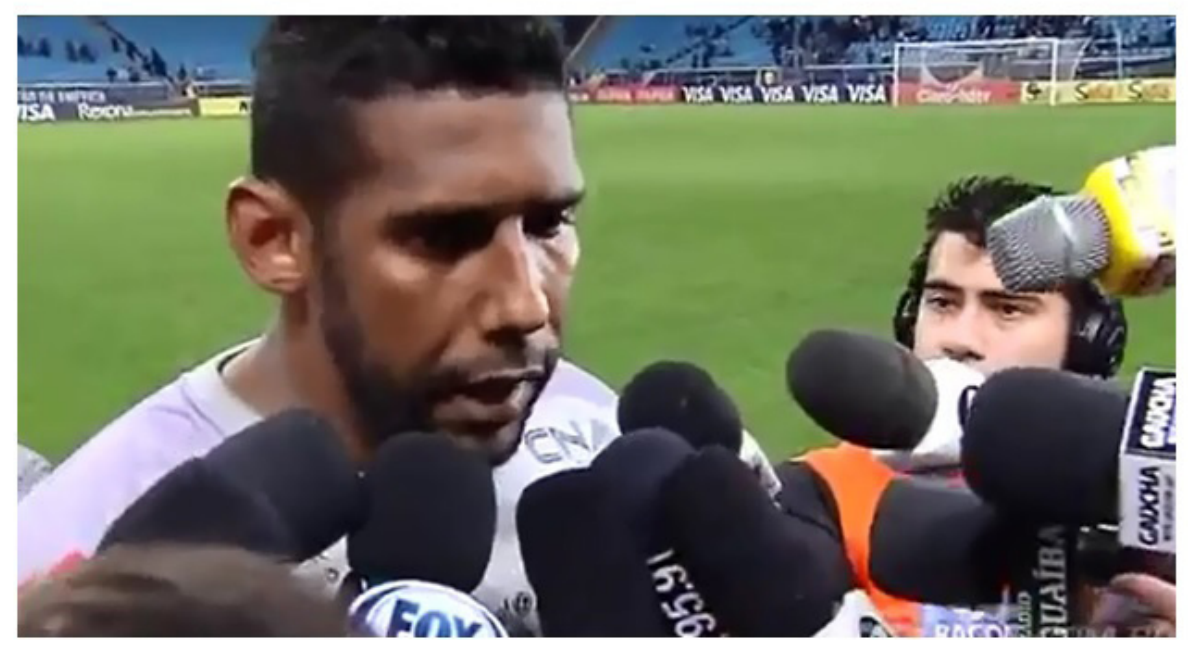

Fonte: Uol Mais. São Paulo, 29 ago, 2014. Disponível em

¿http://mais.uol.com.br/view/e0 qbgxid79uv/video-da-espn-mostra-torcedora-do-gremiochamando-aranha-de-macaco-04020D193272DC895326?types=A \&>Acesso em 02 out. 2014. 
Essa metáfora se encaixa dentro de atores individuais midiatizados, uma vez que demonstra a posição do goleiro do Santos no final do jogo. Aranha acusa a torcida, mas sugere que não vai propagar o assunto. Sua ação até o momento é pelo fechamento do caso como registro midiático. Entretanto, o caso midiático já estava aberto.

O C2, apresentado no esquema da figura 2, representa a propagação da imagem da ESPN a outros veículos de comunicação. Antes mesmo do jogo entre Grêmio e Santos terminar, a imagem de Patrícia Moreira era reproduzida por diferentes veículos de comunicação, sobretudo com o pronunciamento da palavra 'ma-ca-co'.

Figura 11 - Reprodução da imagem pelo Jornal Zero Hora

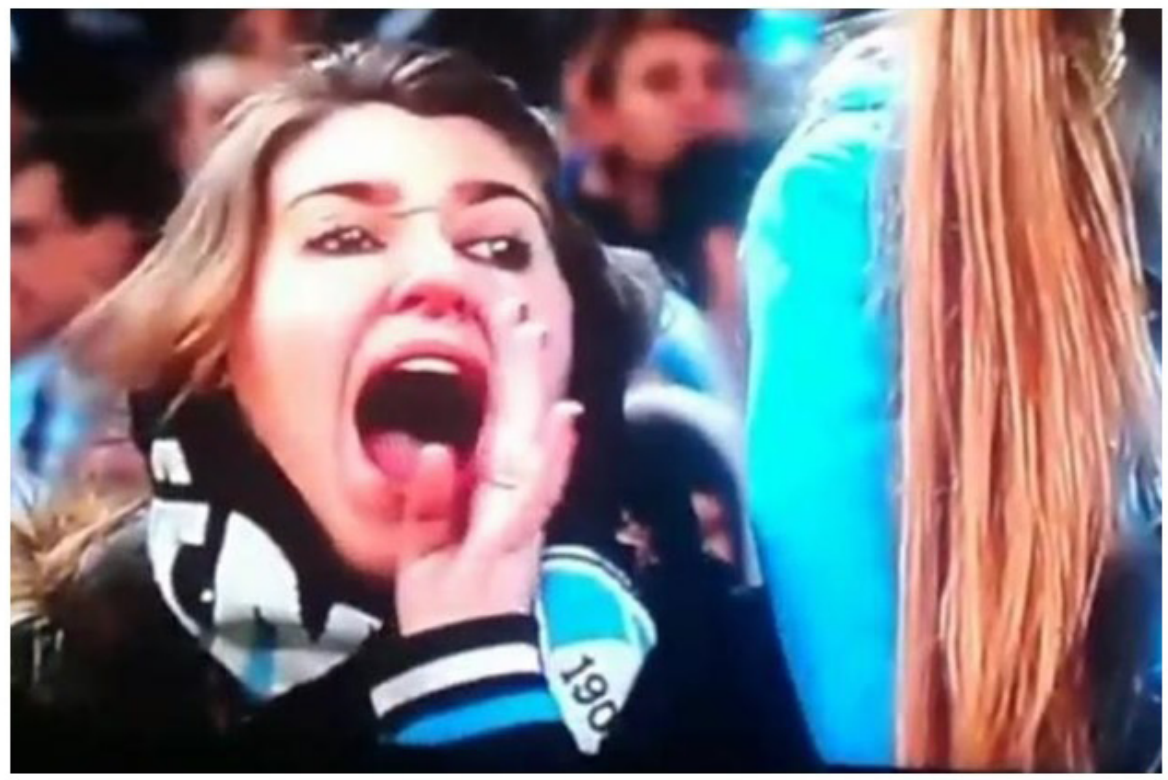

Fonte: Zero Hora. Porto Alegre, 29 ago. 2014. Disponível em $\varangle$ http://zh.clicrbs.com.br/rs/esportes/gremio/noticia/2014/08/torcedora-que-cometeu-ato-racistana-arena-e-afastada-do-trabalho-4586218.html >. Acesso em 05 set. 2014.

As instituições midiáticas propagam a expiação, a focalização, dando, ao episódio, um caráter específico, que o retira do equilíbrio já estabelecido - na cultura midiática - quando ocorrer uma acusação geral às torcidas.

O "Eu te Acuso" se instala neste momento. O movimento efetuado pelo goleiro Aranha de chamar o canal ESPN e enfrentar o grupo de torcedores gerou, na sequência, a criação da personagem principal do caso midiático. A classificação C3 reporta-se a Patrícia Moreira, acusada pelas injúrias proferidas em campo. Mesmo com um grande grupo de torcedores realizando ofensas, a culpa ficou sobre a torcedora Patrícia, que teve sua imagem repetida em diferentes meios. Logo que saiu da Arena do Grêmio, a jovem recebeu ligações de familiares e amigos, comentando a dimensão do acontecimento, conforme relato ao apresentador Celso Portiolli do programa Domingo Legal do SBT. 
Figura 12 - Reprodução de entrevista ao programa do SBT

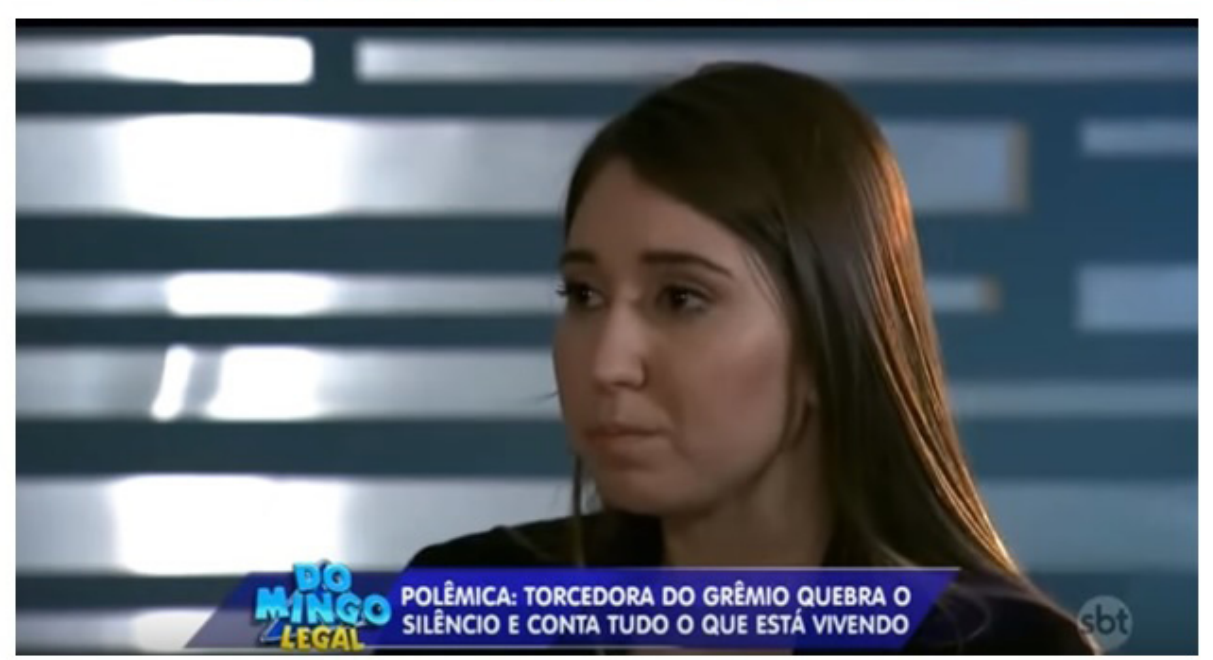

Fonte: SBT Domingo Legal. São Paulo, 15 set. 2014. Disponível em বhttps://www.youtube.com/watch?v=VU-28QS2KoU>. Acesso em 23 out. 2014.

Patrícia Moreira é acusada sem ter saído do estádio, pois a imagem do seu pronunciamento silábico já havia sido repetida antes mesmo do término da partida. A torcedora é descoberta e sua imagem propagada. A descrição se insere em atores individuais, pois remete à ação de Patrícia em meio ao conjunto da torcida.

O C4 faz menção aos perfis de Patrícia Moreira, que são encontrados nas redes sociais facebook e twitter. A metáfora - por analogia - é o "Procurase”. A partir da identificação da torcedora pelas instituições midiáticas e midiatizadas, iniciam as ofensas e os xingamentos devido ao registro feito pelo canal ESPN. Expressões ficaram registradas em seu perfil: "Vai pra cadeia, racista", E esse preto na sua camisa, racista!", "Lixo", "Vacilona", sendo que palavras mais fortes foram retiradas de circulação. É a "Expiação". 
Figura 13 - Imagem das redes sociais da torcedora com xingamentos ESPN

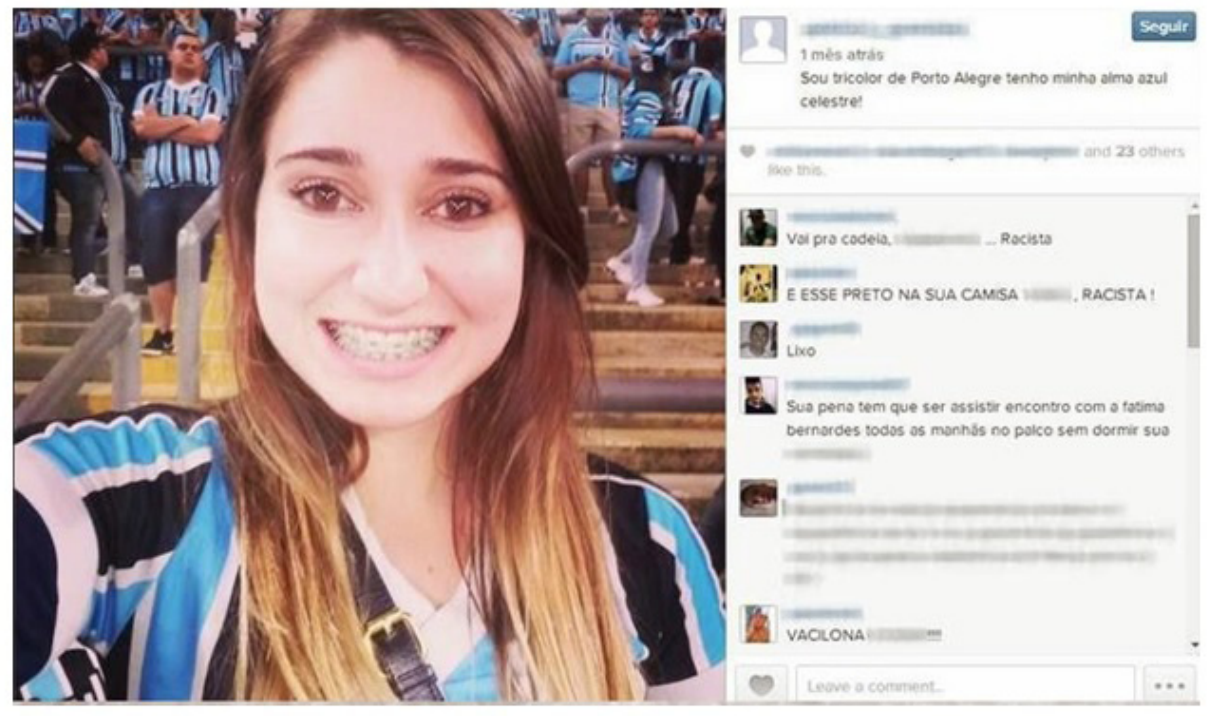

Fonte: Extra. Rio de Janeiro, 29 ago. 2014. Disponível em

४http://extra.globo.com/esporte/perseguida-nas-redes-sociais-gremista-que-fez-xing amentosracistas-aranha-deleta-fotos-apaga-perfis-13769425.html> Acesso em 21 set. 2014.

Os acontecimentos descritos nesse item derivam dos fatos descritos no item $\mathrm{C}$, que correspondem à propagação da imagem da Patrícia Moreira nas instituições midiáticas e midiatizadas. Ou seja, o sucessivo uso da imagem da torcedora a torna culpada - o "Veredito". Há um julgamento que ocorre nas redes.

\subsection{A terceira onda: 0 vigário e 0 coro}

A procura por Patrícia Moreira nas redes sociais gerou uma movimentação não institucionalizada nas redes sociais.

Figura 14 - Letra D - Símbolo da acusação no sistema de bifurcações

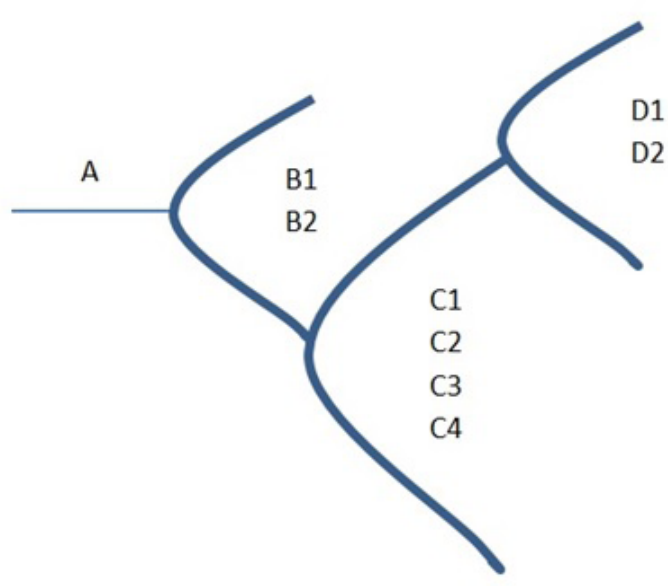

Fonte: elaborado pela Autora(2016).

A partir deste fato, surge o D1, que corresponde ao registro policial de crime de racismo feito por Aranha contra torcedores gremistas. A ida até a 
Delegacia ocorreu em Porto Alegre, na tarde de 29 de agosto, dia seguinte ao jogo. Transforma-se no "Vigário midiático".

Figura 15 - Reportagem destaca denúncia em delegacia de Porto Alegre

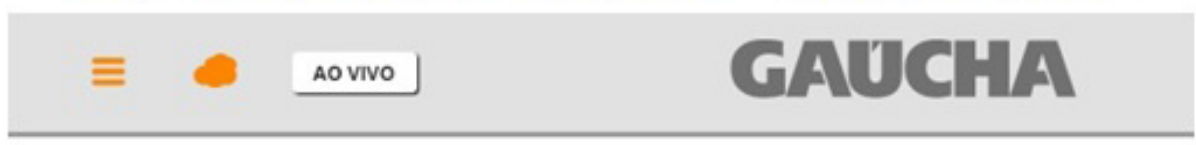

\section{Goleiro do Santos registra ocorrência sobre ato de racismo}

\section{Aranha disse, em depoimento em delegacia de Porto Alegre, que ofensas partiram de torcedores da Geral do Grêmio}
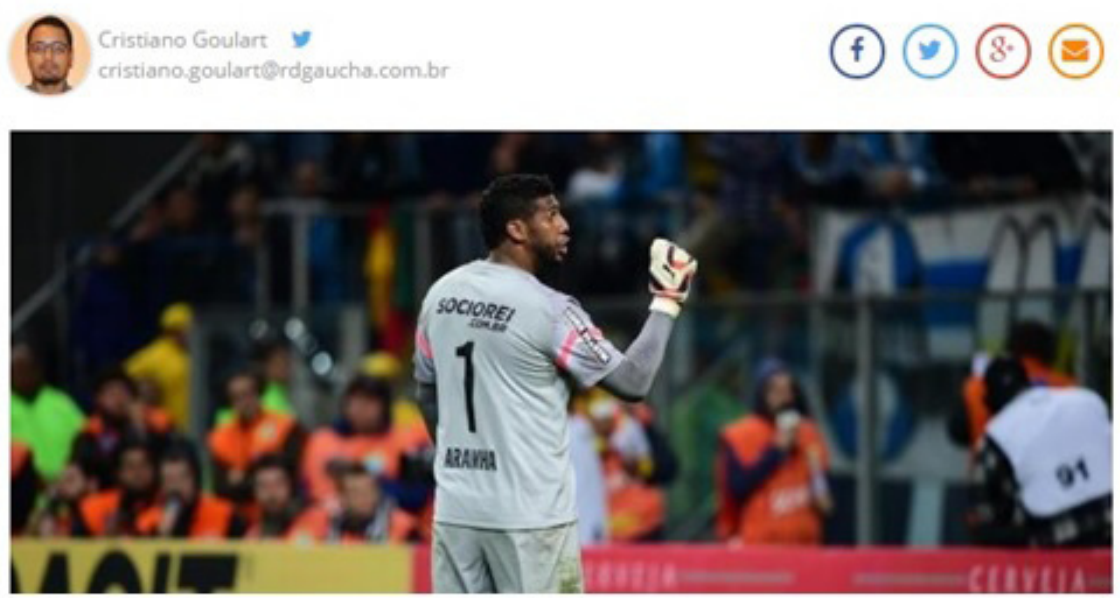

Fonte: GOULART. Cristiano. Porto Alegre, 29 ago. 2014. Disponivel em http://gaucha.clicrbs.com.br/rs/noticia-aberta/goleiro-do-santos-registra-ocorrencia-sobre-atode-racismo-114327. html >. Acesso em 11 nov. 2014.

Ao registrar a ocorrência, Aranha toma a frente novamente do caso e vira uma espécie de delegado ou "vigário" de acusação. Ele assume para si o enfrentamento do assunto e, por isso, a metáfora também corresponde à ação dos atores individuais.

Ao mesmo tempo em que a denúncia é feita na Delegacia de Polícia, as instituições midiáticas resgatam outros casos de racismo no futebol. O D2 reporta-se à memória midiática, que é atualizada para discussão do tema. Os insultos ao goleiro Aranha retomaram antigos acontecimentos relacionados, como a ofensa ao jogador Daniel Alves, que teve bananas jogadas no campo de futebol no exterior, e à Tinga, enquanto jogador do time colorado em partida contra o Juventude. Os fatos geraram movimentação nas redes sociais e a defesa dos jogadores pela sociedade, inclusive através das hadtags \#fechadocomotinga e \#somostodosmacacos. Instalam-se diversas vozes em "Coro". 
Figura 16 - \#fechadocomotinga

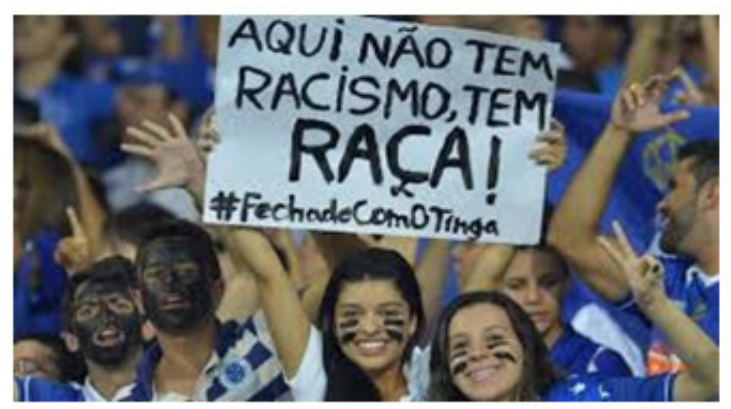

Fonte: Diário Celeste. Minas Gerais, 20 maio 2013. Disponível em $<$ http://diarioceleste.com.br/valeu-tinga $>$ Acesso em 13 out.2014

Figura 17 - Daniel Alves e a banana atirada no campo

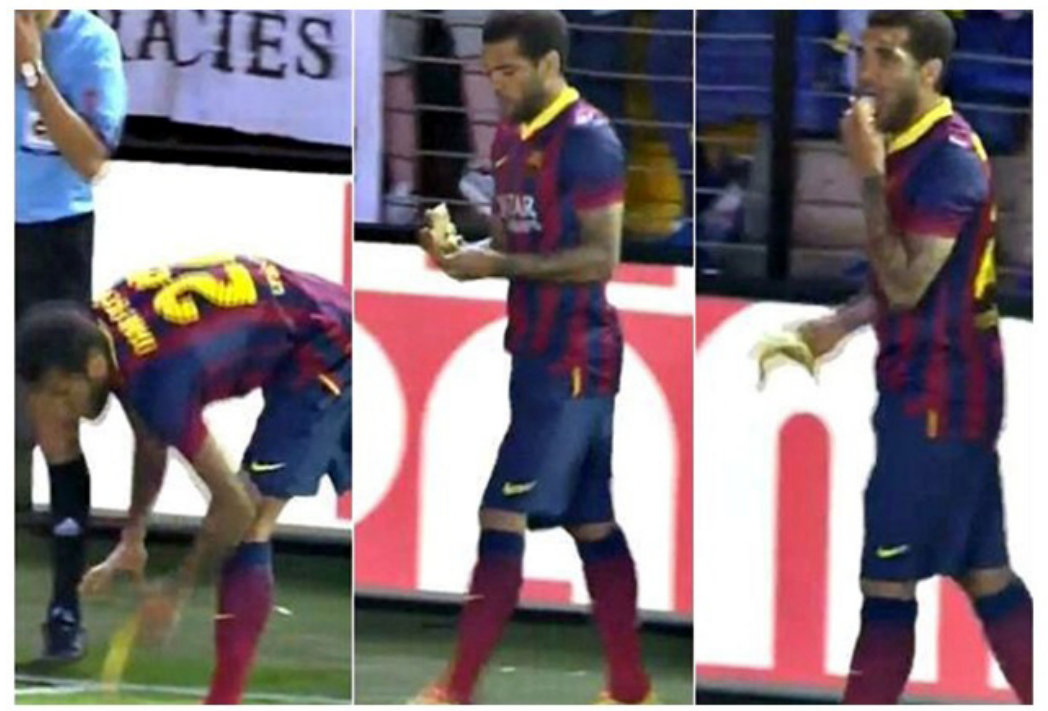

Fonte: ZIRPOLI, Cassio. Pemambuco, 17 abr. 2014. Disponível em

$<$ http://logs.diariodepemambuco.com.br/esportes/2014/04/27/a-resposta-surpreendente-dedaniel-alves-ao-racismo/> Acesso em 10 out.2014

Esse resgate tem relação com o papel das instituições midiáticas, que se reconhecem mutuamente (efeitos de agenda). A retomada de casos antigos de racismo no futebol gera também um fortalecimento da propagação, e, implicitamente, é uma espécie de insumo à acusação.

\subsection{A quarta onda: "0s justiceiros"}

Agora, ganha força, dobrada, pelas posturas dos atores individuais e da indústria cultural, que faz coro e torcida pelo julgamento moral. 
Figura 18 - Letra E - Símbolo da propagação territorial no sistema de bifurcações

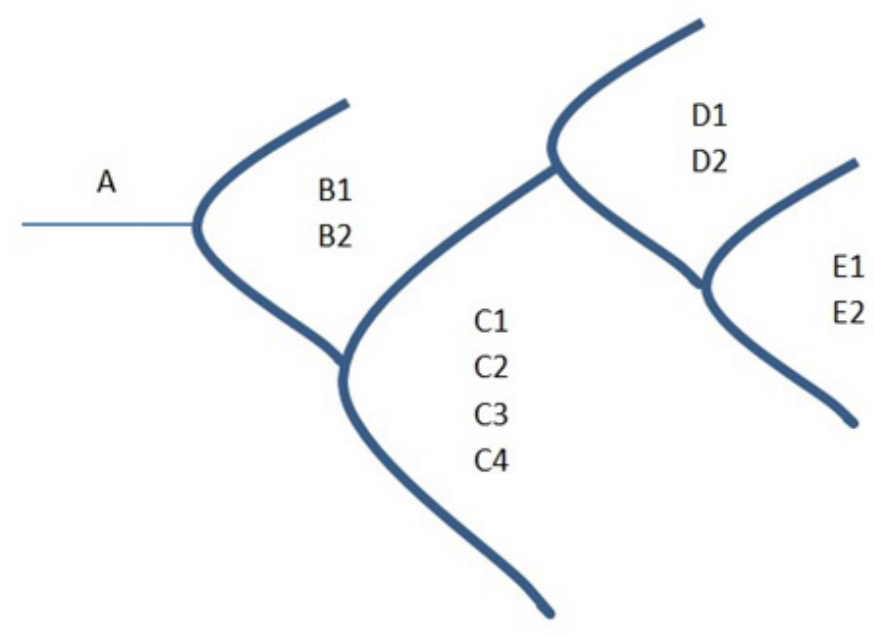

Fonte: elaborado pela Autora(2016).

Os pontos aqui listados são derivados dos acontecimentos anteriores, que marcam a descoberta da torcedora nas redes sociais. Este fato teve consequências, inclusive, na vida pessoal da Patrícia Moreira. No dia seguinte ao jogo, a torcedora foi afastada de suas atividades como Auxiliar de Saúde Bucal do Centro Médico Odontológico da Brigada Militar (PM gaúcha).

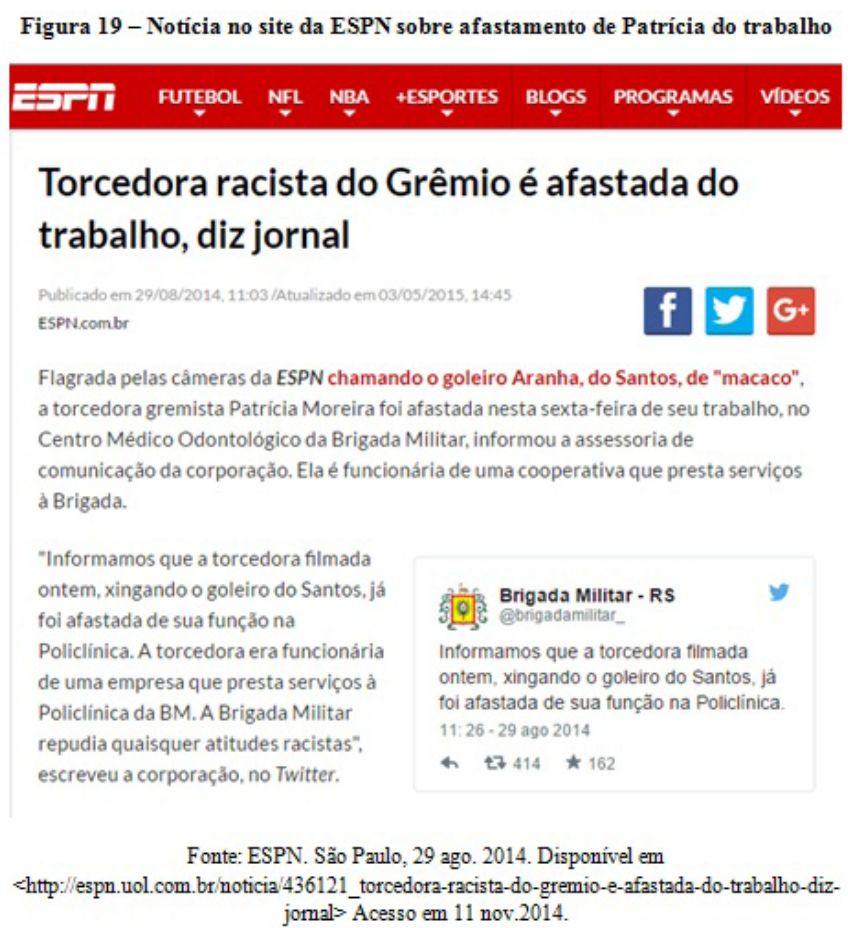

Na noite do dia 30 (dois dias após o jogo), Patrícia teve a casa apedrejada por vizinho e, aproximadamente, uma semana após o jogo, sua casa foi queimada em Porto Alegre, conforme noticiam as matérias da imprensa. 
Figura 20 - Notícia repercute apedrejamento na casa da torcedora

\section{GAZETAONLINE}

\section{Torcedora flagrada xingando goleiro} de macaco tem casa apedrejada

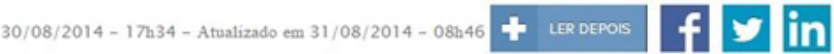

Patrícia Moreira da Silva, de 23 anos, é procurada pela Polícia Civil, mas não está na condição de foragida

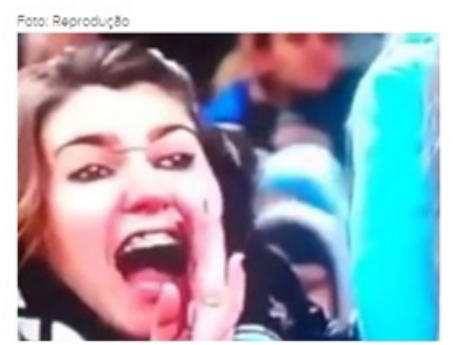

$$
\text { A jovem que fol flagrada }
$$

chamando de "macaco" o goleiro Aranha, do Santos, durante o jogo contra o Grêmio, na última quintafeira, em Porto Alegre, teve a casa apedrejada na noite dessa sextafeira.

Segundo testemunhas, um vizinho arremessou pedras contra uma das janelas da residéncia, localizada no bairro Passo das Pedras, na zona

Fonte: Gazeta Online. Grande Vitoria, 30 ago. 2014. Disponível em Shttp://www.gazetaonline.com.br/ conteudo/2014/08/noticias/brasil/1496140-torcedoraflagrada-xingando-goleiro-de-macaco-tem-casa-apedrejada-html $>$ Acesso em 02 set.2014.

Figura 21 - Jornal Gazeta do Povo comenta desdobramentos de incêndio

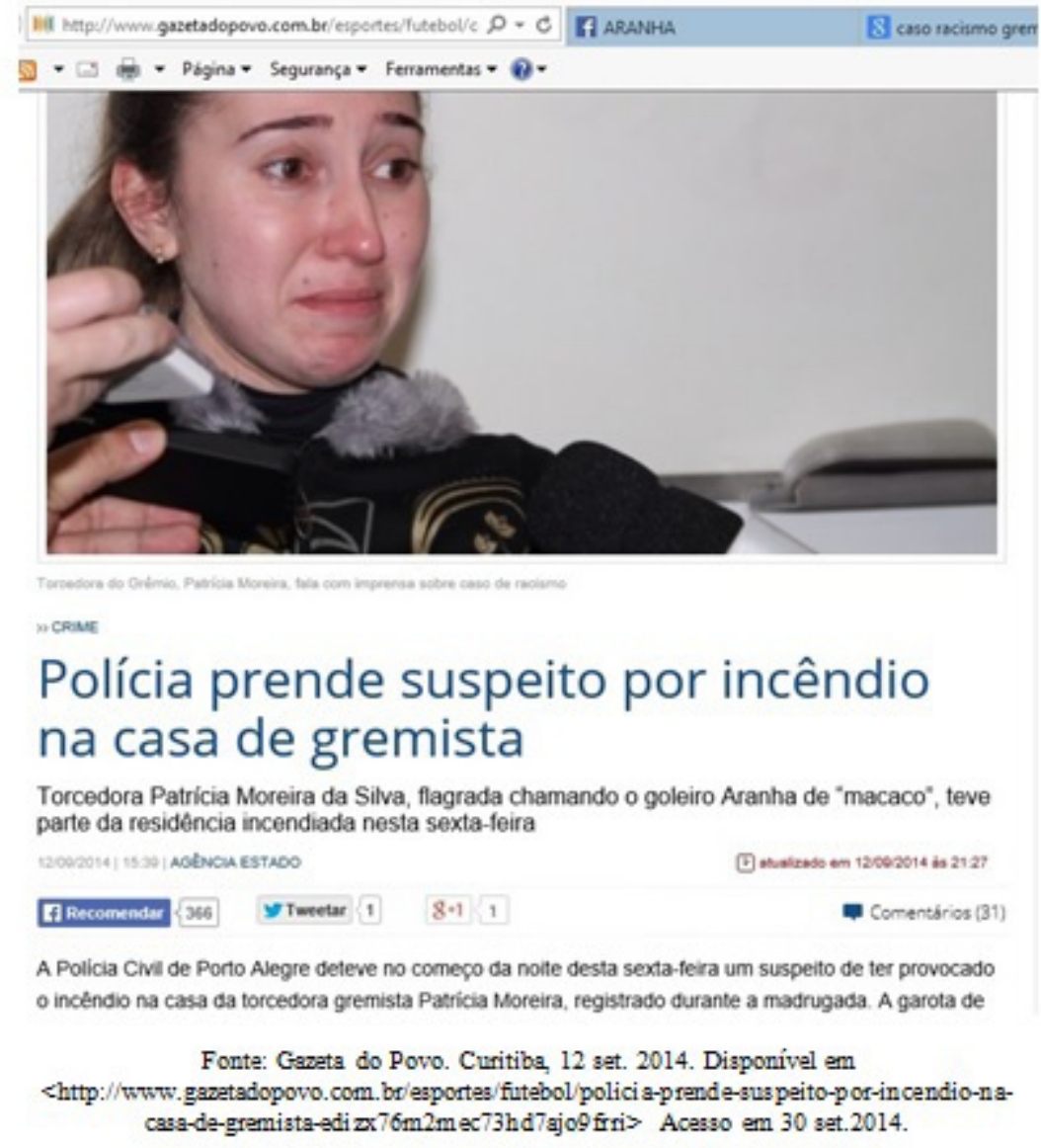

A propagação do tema para o território off-line é indício da força dos processos midiáticos sobre os processos sociais desenvolvidos em outros territórios, antes clássicos, visitados pelas ciências sociais. Neste ponto temos a ação da instituição midiatizada Brigada Militar, que rapidamente faz "justiça”" e afasta 
a torcedora de suas funções no órgão público, além da ação dos torcedores e vizinhos que se empoderaram do direito de defender o clube diante do acontecimento através da agressão aos bens particulares de Patrícia.

\subsection{Agonística no Tribunal de Atores e instituições midiatizadas - 0 caso reaberto}

\section{Figura 22 - Letra F - Agonística no tribunal de atores no sistema de bifurcações}

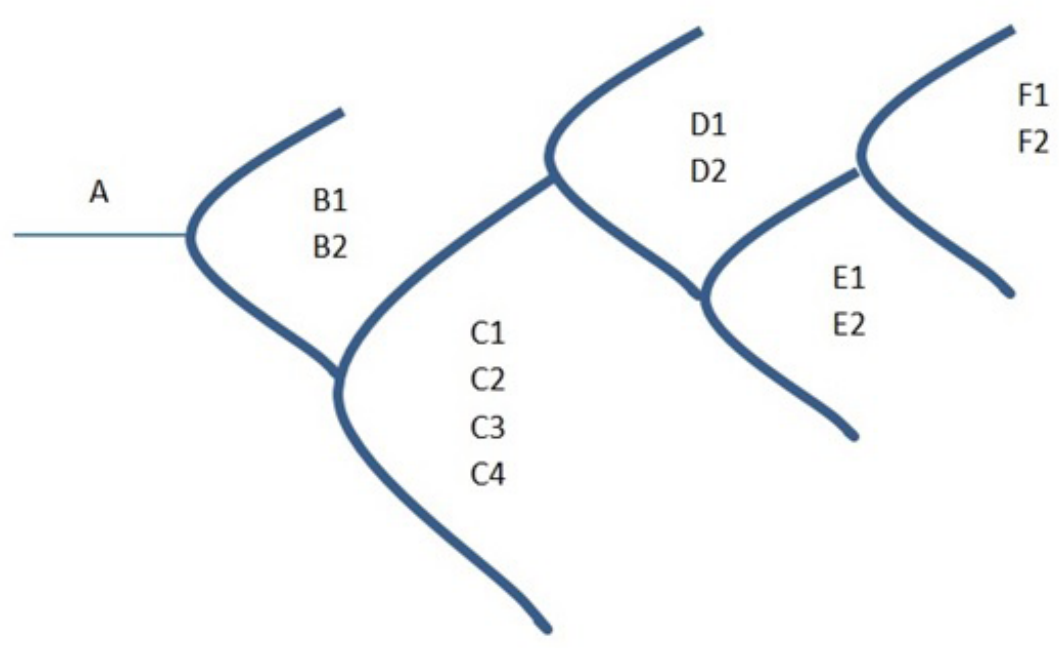

Fonte: elaborado pela Autora(2016).

A propagação da imagem da torcedora como protagonista do pronunciamento racista gerou também a convocação de entidades e personalidades para comentarem o assunto. Dentre vários comentários, destacamos um favorável e um contrário ao posicionamento do goleiro Aranha frente aos insultos recebidos no jogo contra o Grêmio.

Pelé, "o rei do futebol", figura conhecida mundialmente, critica reação do goleiro Aranha às ofensas racistas. Segundo entrevista para o Portal Forum, Pelé disse que Aranha se precipitou ao enfrentar a torcida.

O Aranha precipitou-se um pouco querendo brigar com a torcida. Se eu fosse parar o jogo ou gritar desde quando comecei a jogar, na América Latina, aqui no Brasil e no interior, toda vez que me chamassem de crioulo ou de macaco, aí todo jogo teria que parar. (PELÉ, 2014.) 


\section{Figura 23 - Manifestação de Pelé repercutiu em diversos veículos}

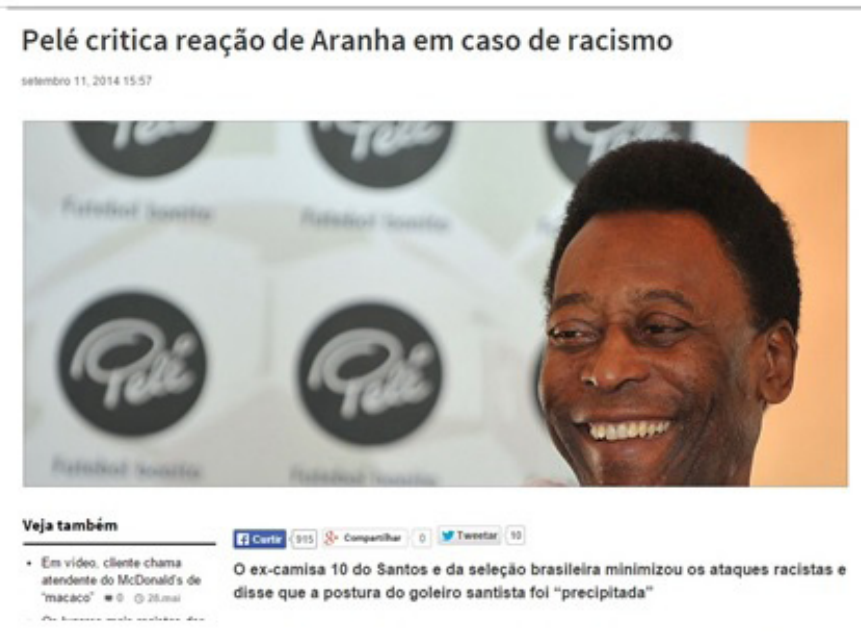

Fonte: Revista Forum. São Paulo, 11 set. 2014. Disponível em http://www.revistaforum.com.br/2014/09/11/pele-critica-reacao-de-aranha-em-caso-deracismo/>. Acesso em 28 nov. 2014.

Já o comediante Helio de la Peña publicou artigo no seu blog denominado "A teia do Aranha", apoiando a atitude do jogador.

Xingar um negro de macaco não tem esse peso todo - para quem xinga. É tão comum que a pessoa nem mais percebe a intenção que é botar a pessoa ofendida pra baixo, lembrar-lhe que é inferior e assim, quem sabe, afetar seu desempenho em campo. Por isso Aranha fez bem em parar o jogo e procurar o juiz quando foi ofendido. Chamou atenção para o ato e provocou uma punição inédita. Injusta? Exagerada? É uma discussão, já que não era um caso isolado no futebol. Mas o fato é que é preciso frear esse tipo de atitude e teria de começar em algum momento, em algum lugar. (HELIO DE LA PEÑA, 2014).

Figura 24 - Imagem de abertura do Blog de Helio de la Peña

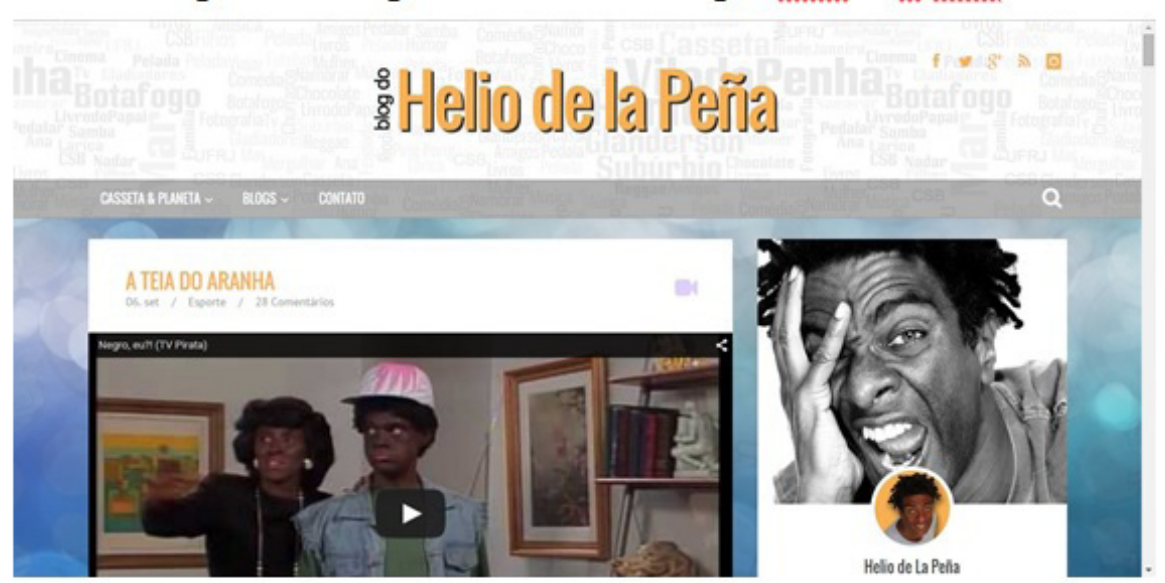

Fonte: LA PEÑA, Helio de. São Paulo, 06 set, 2014. Disponivel em http://www.casseta.com.br/lapena/2014/09/06/a-teia-do-aranha/ ${ }^{/}$Acesso em 29 set.2014.

O tribunal de atores indica que o caso-dilema também se propaga, com força, no campo midiático. 
Figura 25 - Letra G - Símbolo do tribunal esportivo no sistema de bifurcações

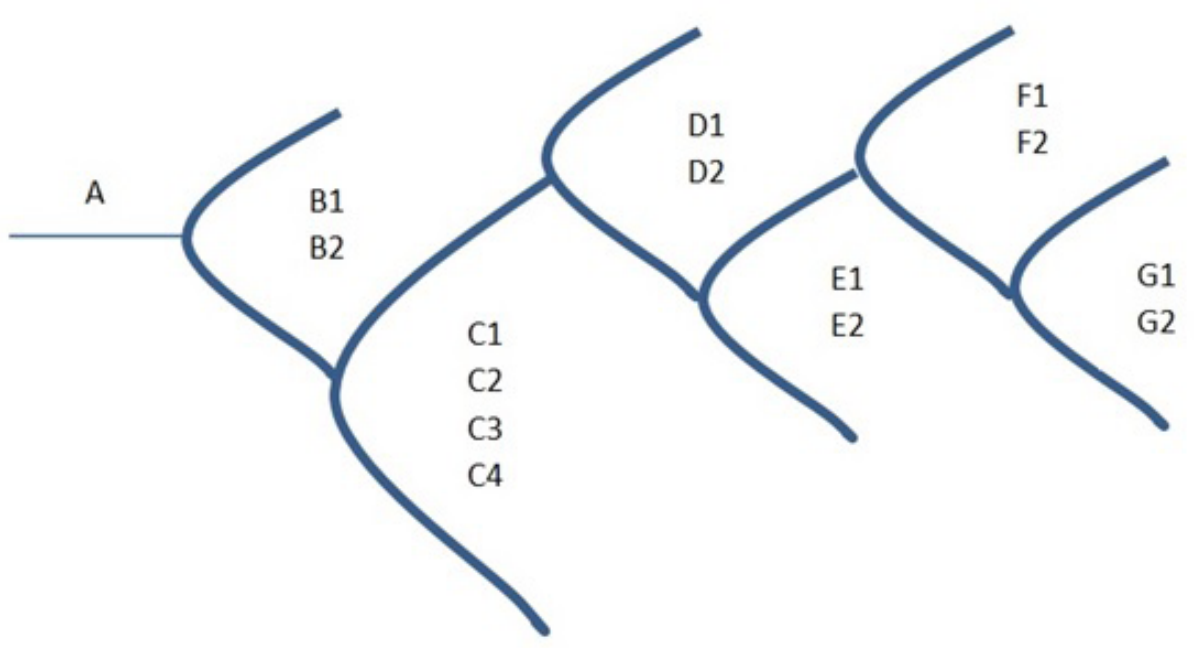

Fonte: elaborado pela Autora(2016).

As instituições midiatizadas entram em campo para participar do caso Aranha. Inicialmente, veio a eliminação do Grêmio da Copa do Brasil pelo racismo praticado por um grupo de torcedores do clube. A ação do Superior Tribunal de Justiça Desportiva votou pela eliminação do clube da competição, por mais que, em segundo momento, após pedido de revisão do clube, tenha optado apenas pela retirada de pontos do Grêmio. Evidente, no julgamento, o efeito blow-up, em curso, quando se observa um dos juízes do tribunal destacando, ao colegiado, a imagem de Patrícia Moreira gritando a palavra ma-ca-co.

Figura 26 - Recorte de matéria da Revista Veja

Futebol

\section{Ofensas racistas da torcida causam eliminação do Grêmio}

STJD decide punir o clube gaúcho de forma rigorosa. Santos está nas quartas de final da Copa do Brasil. Árbitro do jogo e seus auxiliares foram suspensos

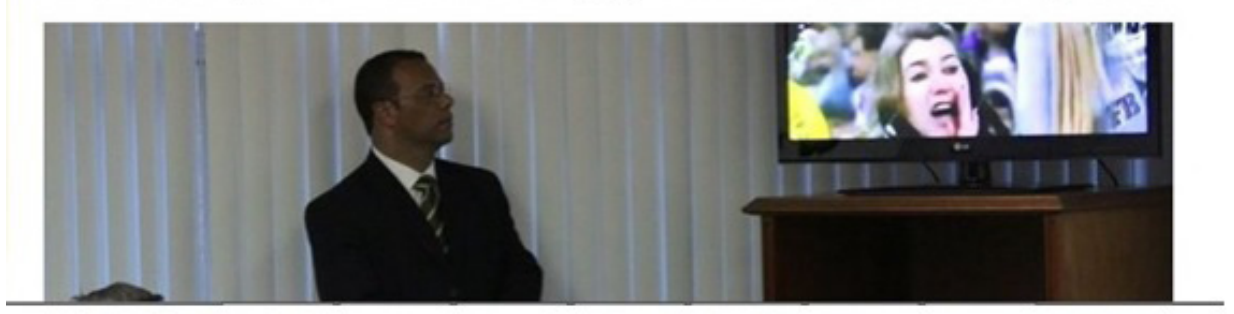

Fonte: Revista Veja. São Paulo, 03 set. 2014. Disponível em $<$ http://veja.abril.com.br/noticia/esporte/no-stjd-gremio-e-eliminado-por-racismo-detorcedores>. Acesso em 21 nov. 2015.

O G2 remete ao fato de um dos auditores do Superior Tribunal de Justiça Desportiva, que votou a favor da eliminação do Grêmio da Copa do Brasil, ter seu perfil vasculhado nas redes sociais. Esta ação é consequência direta da 
decisão tomada pelo tribunal. Em seu perfil, foi encontrado posicionamento racista, em mensagens de 2012 e o auditor pediu afastamento do Tribunal Desportivo devido ao fato. Na imagem, uma criança negra está enrolada em um rótulo de refrigerante acompanhada do comentário: "hahahahahahaha. Quer um gole?”.

Figura 27 - Uma das imagens racistas no perfil do Auditor

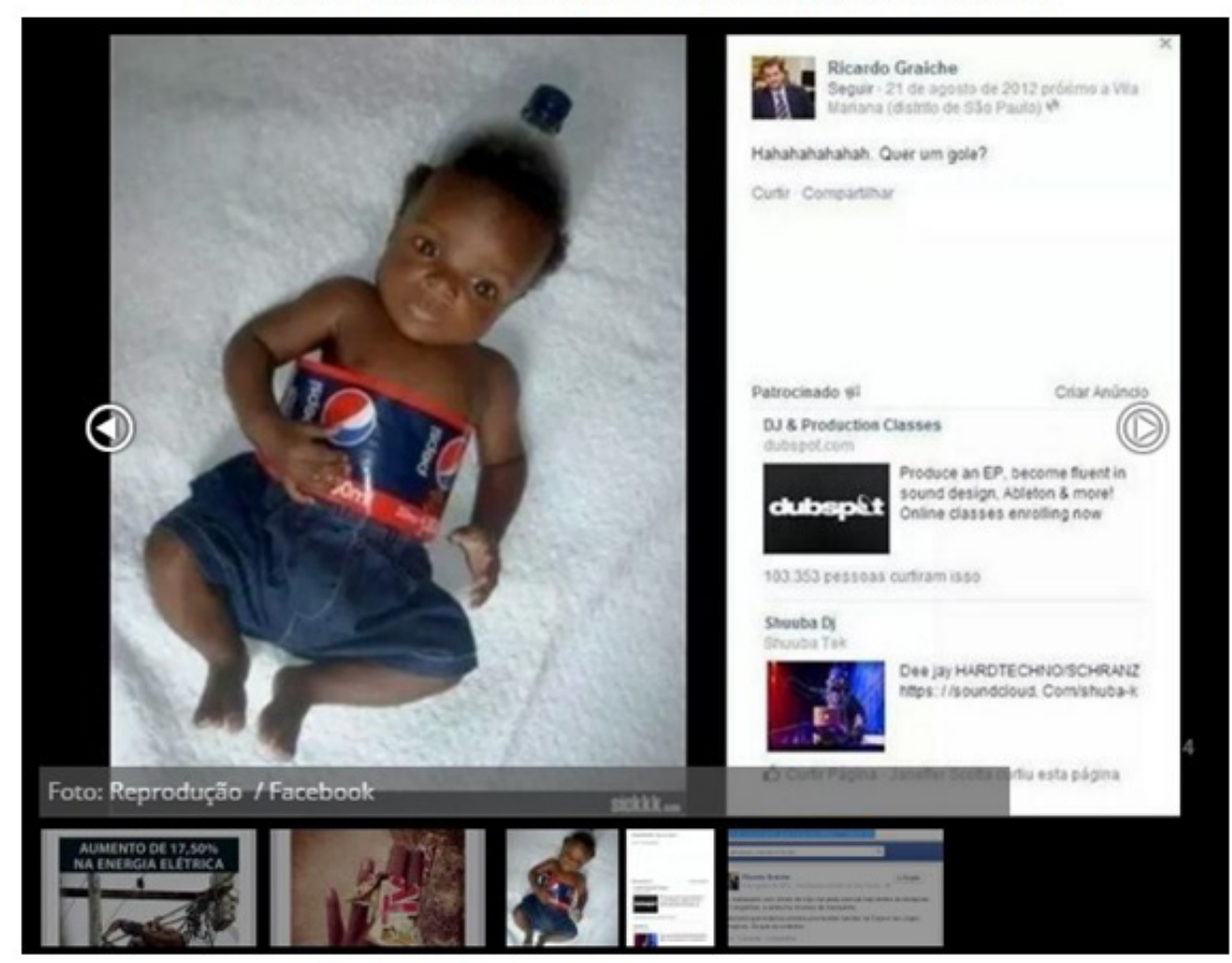

Fonte: GUIMARÃES, Sérgio. Porto Alegre, 04 set. 2014. Disponível em http://gaucha.dicrbs.com.br/rs/noticia-aberta/auditor-que-publicou-mensagens-racistas-emrede-social-pede-licenca-do-stjd-115303 html> Acesso em 01 out. 2014.

A expansão para o território de outras instituições midiatizadas (STJD) propaga e reinstala o dilema, noutro plano, onde atores retroagem ao julgamento dos julgadores.

\subsection{Dilema Ético - Instituições Midiáticas. Instituições Midiatizadas e Atores midiatizados}

A perseguição sofrida pela torcedora do Grêmio e o posicionamento do goleiro frente ao caso ocasionaram, em um certo momento, uma inversão de papéis diante dos micro-acontecimentos. Após um aparato de acompanhamentos para entrevistas, Patrícia Moreira resolve dar seu primeiro depoimento ao programa Encontro com Fátima Bernardes, da Rede Globo de Televisão.

O H1 corresponde ao fato da Patrícia Moreira ceder entrevista exclusiva, sendo que, na ocasião, Patrícia pediu desculpas ao goleiro Aranha, ao vivo, e se torna também uma espécie de vítima do acontecimento. Coloca-se como a "Vítima". 
Figura 28 - Letra H - Símbolo do dilema ético no sistema de bifurcações

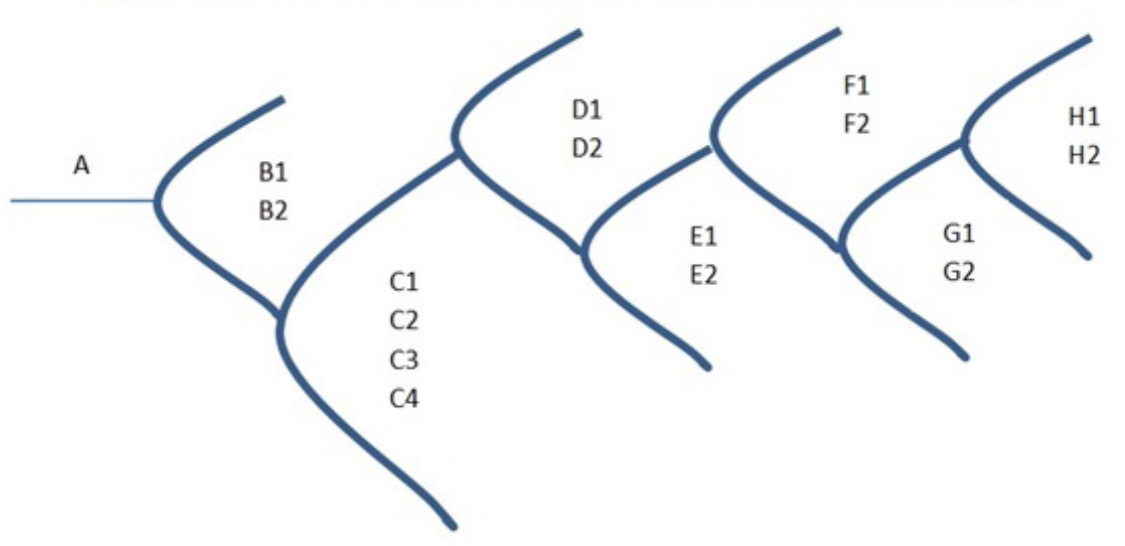

Fonte: elaborado pela Autora(2016).

Figura 29 - Imagem da entrevista exclusiva ao programa Encontro

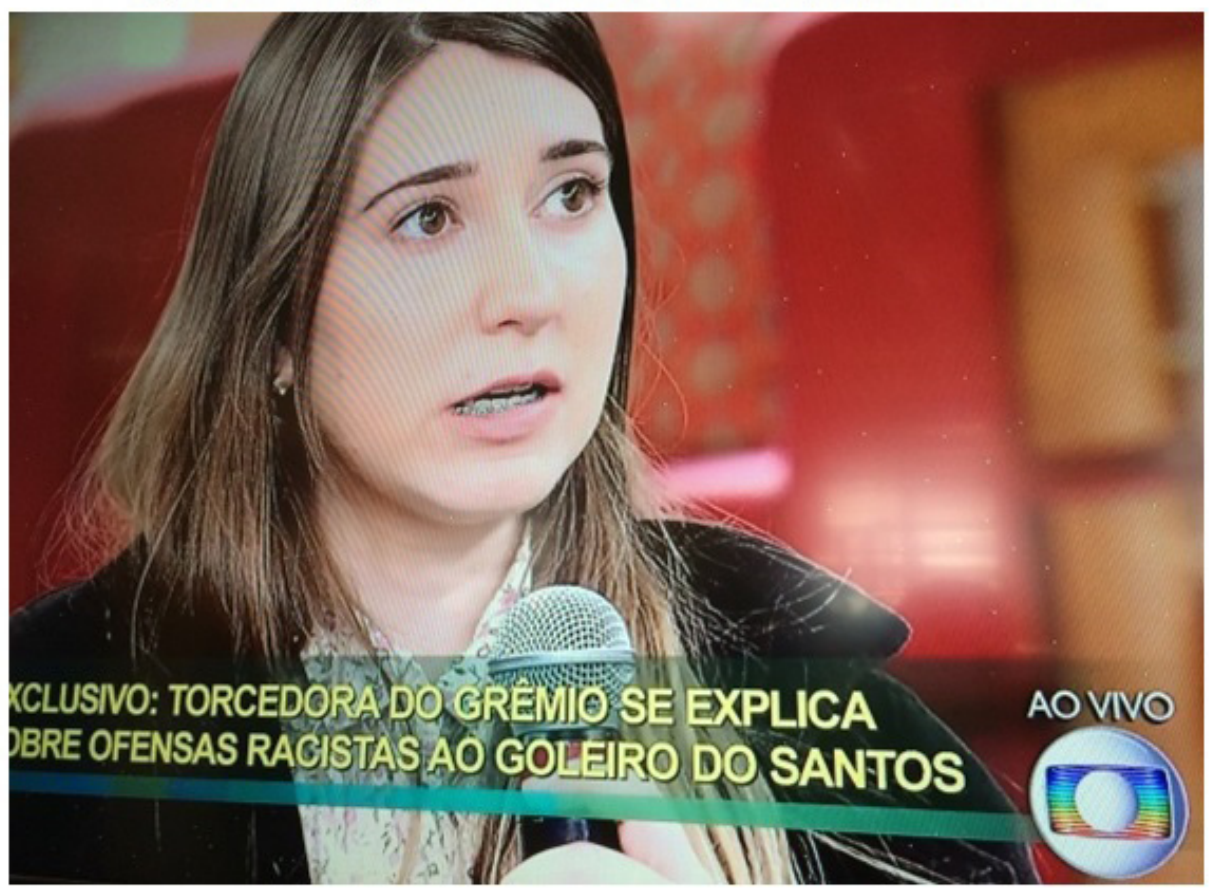

Fonte: Rádio Gaúcha. Porto Alegre, 09 set. 2014. Disponível em

http://gaucha.clicrbs.com.br/rs/noticia-aberta/na-tv-torcedora-relata-ameacas-e-pededesculpas-a-comunidade-negra-115785 html >. Acesso em 11 set. 2014.

Por outro lado, Aranha é ovacionado pela torcida do Atlético Mineiro em jogo no mês de setembro de 2014. O clube, enquanto instituição midiatizada, mobilizou campanha com torcedores pelas redes sociais para apoiar o jogador santista. Manchete do subtítulo de site local destacou: "Tratamento dado ao goleiro santista foi o oposto do ocorrido no Rio Grande do Sul". Evidencia-se, aqui, o contato entre territórios simbólicos. Mesmo que o sul possa aparecer como bode expiatório de algo que também pode estar lá, em Minas. Aranha, o "Mito" está em tensão com Patrícia, a "Vítima". 
Figura 30 - Manifestação de torcida de apoio ao goleiro Aranha Goleiro Aranha, do Santos, é ovacionado por
torcida do Galo no Horto antes de partida

Tratamento dado ao goleiro santista foi o oposto do ocorrido no Rio Grande do Sul

\begin{tabular}{|c|c|c|c|c|c|c|c|}
\hline T* T- & 응 & (1) & 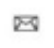 & O compertilher & f Facebook & $8^{+}$Google+ & $\boldsymbol{y}$ Twitter \\
\hline
\end{tabular}

(). postado em 25/09/2014 20:19/atualizado em 25/09/2014 22:09

2 Rodrigo Fonseca/Superesportes

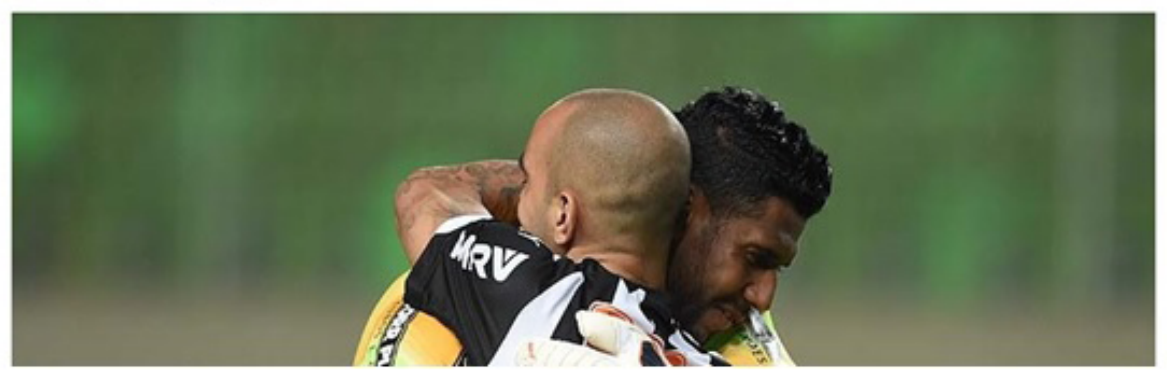

Fonte: FONSECA, Rodrigo. Belo Horizonte, 25 set. 2014. Disponível em $4 \mathrm{http}: / /$ www.mg.superesportes.com.br/app/noticias/futebol/atleticomg/2014/09/25/noticia_atletico_mg,294017/goleiro-aranha-do-santos-e-ovacionado-portorcida-do-galo-no-horto-antes-de-partida.shtml> Acesso em 26 out. 2014.

Na TV Globo, Patrícia Moreira pede desculpas ao goleiro Aranha e quer fechar o assunto polêmico do racismo, mas Aranha, ao receber apoio da torcida do Atlético, continua como promotor e propagador da discussão.

\subsection{A Propagação do Julgamento Moral - Atores Individuais e Instituiç̣̃es Midiáticas}

A partir da entrevista exclusiva de Patrícia Moreira na televisão, Aranha nega pedido de desculpas. $\mathrm{O}$ goleiro disse que perdoou a torcedora, mas não quer encontrá-la. A não aceitação também integra a lógica da propagação do assunto.

Figura 31 - Letra I - Propagação do julgamento moral no sistema de bifurcações

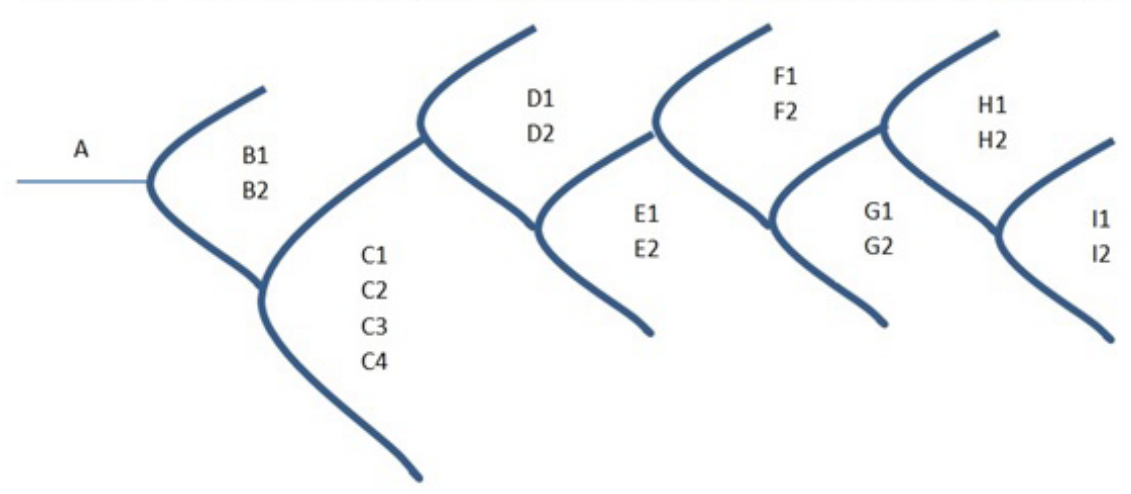

Fonte: elaborado pela Autora(2016). 
Figura 32 - Aranha nega pedido de desculpas da torcedora

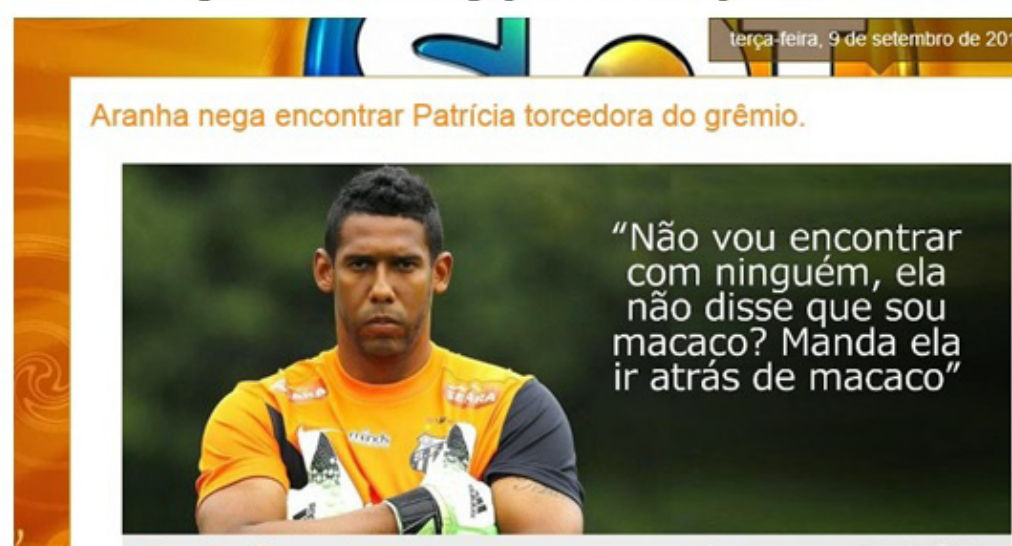

Exclusivo: Aranha nega se encontrar com Patrícia torcedora do Grêmio que supostamente o xingou

O goleiro Aranha não quer, pelo menos por enquanto, encontrar a torcedora gremista Patrícia Moreira, que o ofendeu com injúrias raciais na partida de ida da Copa do Brasil, entre Santos e Grêmio, no dia 28 de agosto. Por meio da assessoria de imprensa do Peixe, o camisa 1 diz que, pelo menos por enquanto, vai esperar a investiga $h$ http://sbt-canal.blogspot.com.br/2014/

09/aranha-nega-encontrar-patricia.html

Fonte: Blog do SBT. São Paulo, 09 set. $201 \mathrm{Ctrl+clique} \mathrm{para} \mathrm{seguir} \mathrm{o} \mathrm{link}$ canal.blogspot.com. br/2014/09/aranha-nega-encontrar-patricia.html> Acesso em 30 set, 2014.

A partir da exposição e fala da torcedora nas instituições midiáticas, começam a circular, com maior velocidade, os memes envolvendo a torcedora Patrícia Moreira enquadrada na figura de "Vítima". As redes sociais não demoraram a criar seus ícones. Os memes demonstram uma parcela dos conteúdos que circularam nos meios digitais com frases como: "Não consigo mais voltar pra minha casa, fico pulando de galho em galho", "Gritar e chamar jogador de macaco é fácil, agora quero ver é gritar campeão". As ações nas redes são protagonizadas por atores individuais, geralmente não institucionalizados. 


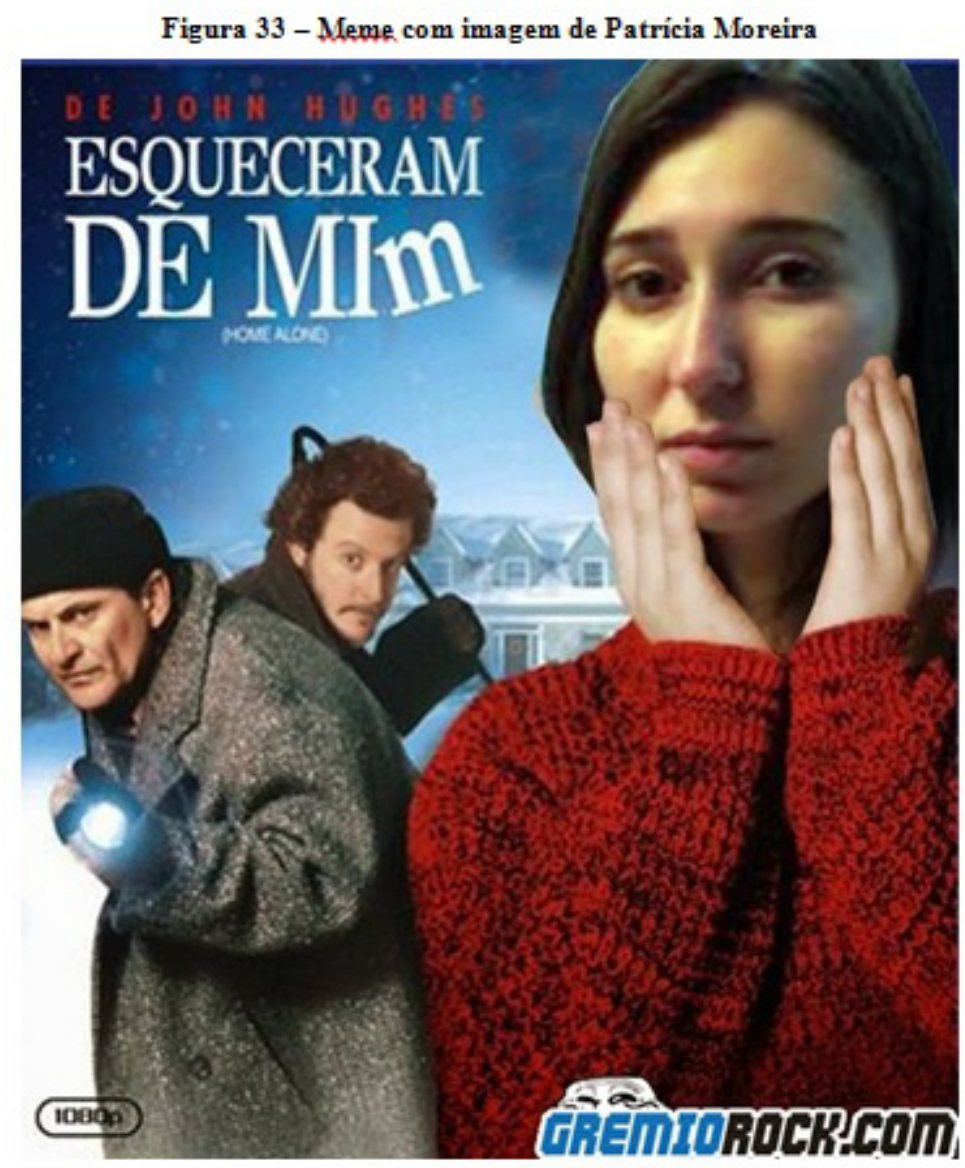

Fonte: Grêmio Rock. Porto Alegre, 27 out 2014. Disponiviel em <http:/www. gremiorock. com/2014/10/patricia-morei ra-staca-novamente-e-vai.html>. Acesso em 10 nov. 2014 .

\subsection{0 "Direito"}

Os ícones da letra J correspondem ao julgamento feito pelo Judiciário sobre a ação do grupo de torcedores gremistas. O julgamento ocorreu em novembro de 2014 e gerou a suspensão do processo penal contra os torcedores do Grêmio. Entra no jogo, o "Direito".

Figura 34 - Símbolo do julgamento legal no sistema de bifurcações

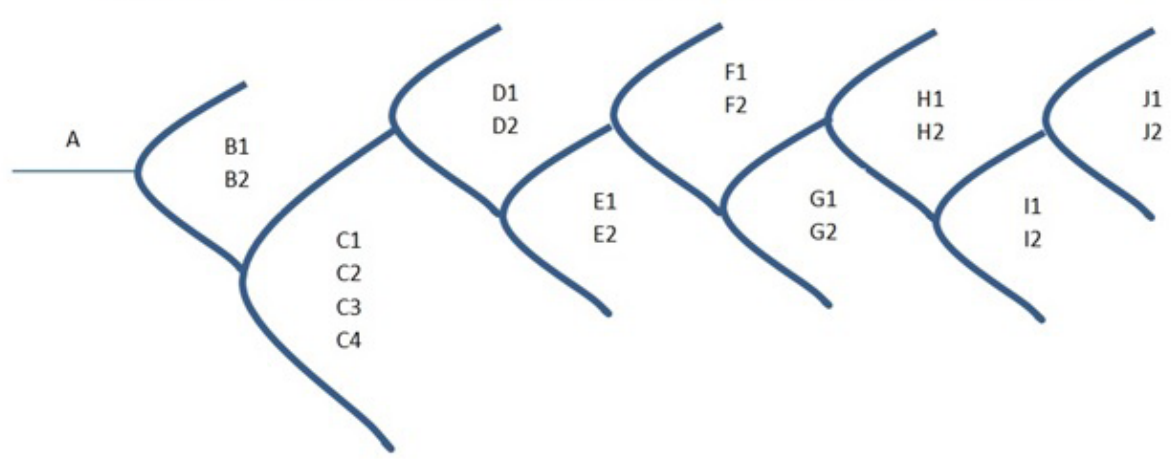

Fonte: elaborado pela Autora(2016). 
Figura 35 - Registro do julgamento do caso

\section{Patrícia Moreira e outros envolvidos terão de ir à polícia em jogos do Grêmio por 10 meses}

Determinação foi apresentada como condição para que o processo penal fosse suspenso

Por: André Baibich

(c) $24 / 11 / 2014$ - 1 Ohis 18 min | Atualizada em 24/11/2014-15h10min

Comparithar 908 8?

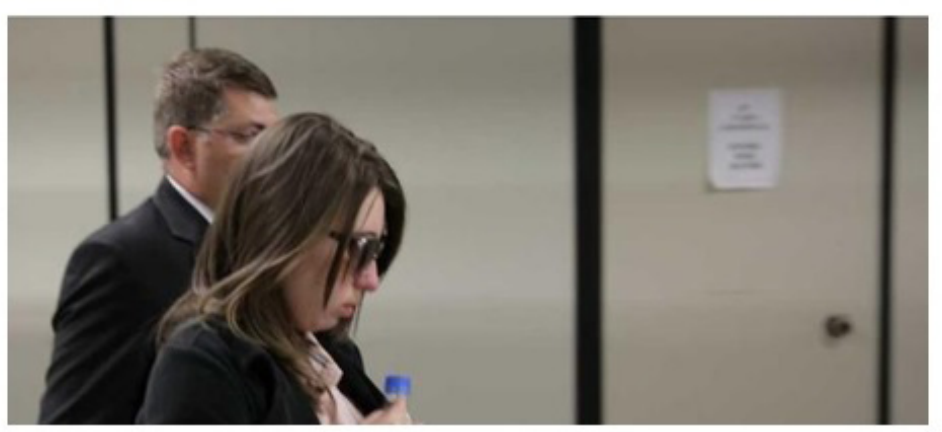

Fonte: BAIBICH, André. Porto Alegre, 24 nov. 2014. Disponivel em $<\mathrm{http} / / / \mathrm{zh}$.clicrbs.com.br/rs/esportes/gremio/noticia/2014/11/patricia-moreira-e-outrosenvolvidos-terao-de-ir-a-policia-em-jogos-do-gremio-por-10-meses-4649464.html> Acesso em 30 nov. 2014 .

O J2 apresenta os desdobramentos do julgamento. A Ordem dos Advogados do Brasil realiza pronunciamento após julgamento dos torcedores do Grêmio: "Falta consciência negra ao Judiciário". 
Figura 36 - Comentário sobre julgamento de torcedores gremistas

$\begin{array}{llllll}\text { R7 Notícias } & \text { Entretenimento Esportes } & \text { Vídeos } & \text { Red } \\ \text { gazsícil Vídeos Fotos Assinante } \\ \text { Capa Cadernos Edição Multimídia Colunas e Blog Articulistas Entretenimento Grupo G: }\end{array}$

Esporte

8. compartihar 0 Tweetar

Terça, 25 de novembro de 2014, 18 h01

SANTOS

\section{Caso Aranha fica sem julgamento; 'Falta consciência negra ao Judiciário', diz OAB}

Redação do R7

Os torcedores gremistas que gritaram ofensas racistas contra o goleiro Aranha, do Santos, nas oitavas de final da Copa do Brasil, não chegaram a ser julgados pelo crime de injúria racial. Eles foram, no entanto, punidos em um acordo selado com o juiz Marco Aurélio Xavier em audiência no Foro Central de Porto

Fonte: MENDONÇA, Renata. São Paulo, 25 nov. 2014. Disponível em $<$ http://esportes.r7.com/futebol/caso-aranha-fica-sem-julg amento-falta-cons cien cia-negra-aojudiciario-diz-oab-25112014> Acesso em 12 dez. 2014.

\section{$4 \quad$ CONCLUSÕES}

O caso de investigação acima é rico para inferirmos uma hipótese: os circuitosambientes midiáticos podem ser constituídos a partir de zonas de instabilidade nas interações, resultantes de defasagens de sentido entre os interlocutores. Ou seja, quanto maior as defasagens, os desequilíbrios de sentido, maior a instabilidade, o que demandaria maior interações para as resoluções sociais tentativas de novas referências de equilíbrio. Essas referências podem vir a ser simbólicas, ou ficarem distribuídas de forma difusa e diferida em figuras, metáforas, enfim, imaginários, entre atores e instituições, midiáticas e midiatizadas. A pesquisa não questiona se há, a partir do caso, uma nova simbólica constituída, mas, desde então, ensaisticamente pode-se inferir que o cenário dos embates culturais no Rio Grande do Sul, se deslocou do signo específico que acionou o processo - macaco - para outros objetos.

Como formulado em outro artigo (Ferreira, 2016), há uma explosão de defasagens no contexto midiático contemporâneo. Os processos midiáticos contemporâneos deixando de ser determinados e regulados por lógicas dos sistemas de produção específicos (Ferreira, 2016), o que, em si, já remete a essas instabilidades. Por outro lado, essas matrizes complexas constituídas em termos macros-midiáticos, se atualizam nos circuitos. Não é possível dizer onde elas vão surgir (princípio da incerteza), mas, no caso relatado neste artigo, envolve:

a) o contato entre simbólicas aproximadas pelos processos midiáticos, que antes estavam em temporalidades e espacialidades diversas, antes relativamente reguladas; 
b) o contato mediado pelo uso dos meios por atores, instituições e coletivos que emergem no processo;

c) uma atualização das disputas simbólicas, de luta pelo reconhecimento, recorrendo-se a metáforas que passam a agenciar o processo.

Entretanto, essas três dimensões não estariam envolvidas, no caso investigado, não fosse um detalhe: o blow up. O blow up demanda o "fotógrafo" (o câmera), o mundo mostrado, o comentarista, a instituição midiática, o fotografado (Aranha e Patrícia) e a cena - em foto, imagem, expressão, em que a torcedora grita "ma-ca-co". Esse passa a ser o catalizador, que remexe com aquilo que é potencial, acionando uma disrupção semiótica. É o ponto de bifurcação, que gera instabilidade os equilíbrios possíveis nos processos midiáticos. Esse ponto é transversal a todos os outros. A sociedade interage em torno da questão: o que ele significa? Os pontos sucessivos são agregações metafóricas, compondo um cenário narrativo do acontecimento, com aberturas de novas possibilidades.

Nesse sentido, é pertinente terminar citando essa passagem que pode condensar dimensão, que envolve os envolvidos:

.... lente é o instrumento primordialmente produtor de significantes; é, sim, filtro, e justamente nesse momento cabe-nos pensar sobre a ideia do duplo, no caso o real e o ficcional (para não incluir aí a questão do imaginário), e mais especificamente a questão de instrumento ampliador, desvendador, transmissor, deturpador da realidade. Ampliador, uma vez que o real, o assassinato do homem no parque, é apenas descoberto após a série exaustiva de blowups do duplo dos personagens em questão (mulher no parque, homem no parque, mão anônima, revólver); desvendador, pois é através da lente que se pode enxergar aquilo que os olhos não poderiam ver - o real, uma vez que é fantástico demais para ser percebido aos olhos; transmissor, pois a lente é o instrumento determinante do surgimento de um par significante, a arma e a mão que a empunha; e finalmente deturpador, pois a realidade, ampliada inúmeras vezes, atinge um grau de deformidade de difícil assimilação - a lente, assim, é deformadora da própria realidade, pois leva os fatos a pontos pouco plausíveis (é, assim, o instrumento expressionista do real), pelo menos segundo um discurso realista que pretende exterminar as arestas de artificialismo que se faça presente. Vale lembrar, contudo, que esse 'real' é um artifício ainda maior, como pode-se perceber no famoso jogo de tênis sem bola com a consequente desaparição do fotógrafo da tela, diante das lentes de um certo 'autor empírico', que deforma, assim, agora num blow down, o fotógrafo, filmado de longe, pequenino na grama verde. (MORETO, 2005, p.1). 


\section{REFERÊNCIAS BIBLIOGRÁFICAS}

FERREIRA, Jairo. A construção de casos sobre a midiatização e circulação como objetos de pesquisa: das lógicas às analogias para investigar a explosão das defasagens. GALÁXIA (PUCSP), v. 33, p. 199-213, 2016.

FERREIRA, Jairo. Poder simbólico no campo das mídias: perspectiva de estudo sobre a circulação do discurso das ONGs em dispositivos digitais na Web. Eptic (UFS), Online, v. VII, n.5, p. 1-15, 2005. FERREIRA, Jairo. Campos de significação e conhecimento em dispositivos digitais: análise das interações discursivas em listas de discussão. Porto Alegre: Programa de Pós Graduação em Informática na Educação - PGIE, 2002 (Tese de Doutorado).

BRAGA, José Luiz. Circuitos versus campos sociais. BRAGA, JL. Circuitos versus campos sociais. In: MATTOS, MA., JANOT'TI JUNIOR, J., and JACKS, N., orgs. Mediação \& midiatização [online]. Salvador: EDUFBA, 2012, pp. 29-52. ISBN 978-85-232-1205-6. Available from SciELO Books .

LA PEÑA, Helio de. A teia do Aranha. São Paulo, 06 set, 2014. Disponível em <http://www.casseta.com.br/lapena/2014/09/06/a-teia-do-aranha/> Acesso em 29 set.2014.

MORETO, Bruno. O Acidental e o Indurido: lentes, Peeping Tom e Blow Up. São Paulo, agosto-setembro, 2005. Disponível em <http://publicacoes. unigranrio.com.br/index.php/reihm/article/viewFile/488/479> Acesso em 20 fev.2016.

PRIGOGINE, Ilya Prigogine. O fim das certezas. São Paulo: Unesp, 1996.

REVISTA FORUM. Pelé critica reação de Aranba em caso de racismo. São Paulo, 11 set. 2014. Disponível em <http://www.revistaforum.com.br/2014/09/11/ pele-critica-reacao-de-aranha-em-caso-de-racismo/>. Acesso em 28 nov. 2014.

VERON, Eliseo. Esquema para El analisis de La mediatización. In: Diálogos, n.48. Lima: FELAFACS, 1997. p 9-17.

VERÓN, Eliseo. Los públicos entre producción y recepción: problemas para una teoría del reconocimiento. Curso da Arrábida: Público, Televisão. 2001.

WATZLAWICK, P, BEAVIN, J. Helmick, JACKSON, Don D. Une logique de là communication. Paris: Editions du Seuil, 1991. 